\title{
تحليل جغرافي لمشكلة السكن العشوائي في مدينة كويه
}

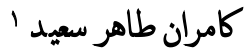 \\ ' قسم الجغرافيا، فاكلتي التزبية، جامعة كويه، إقليم كوردسثان، العراق
}

المستخلص

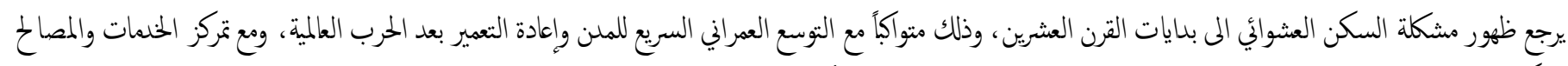

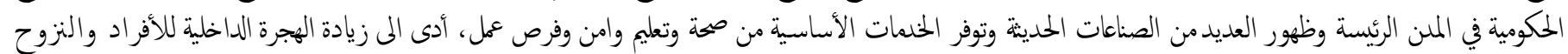

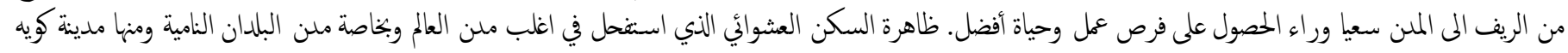

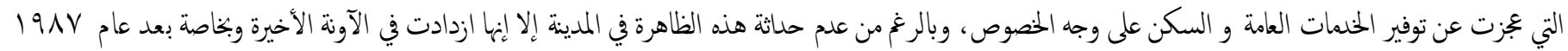

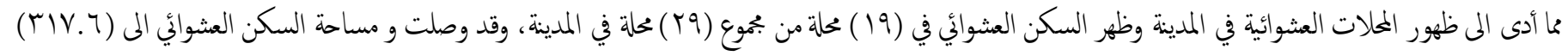

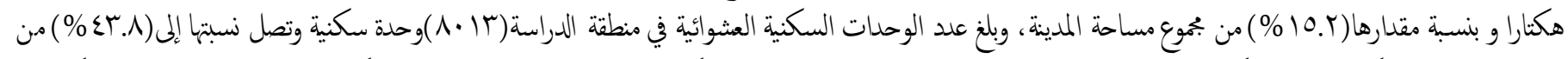

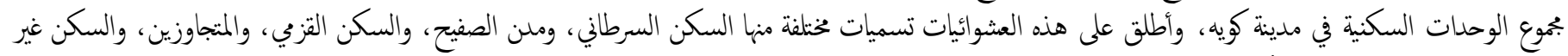

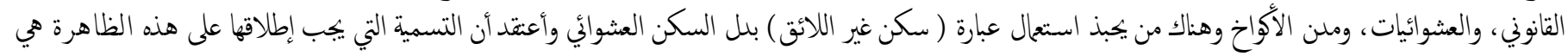

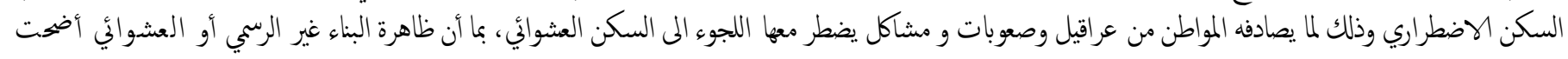

تطوق أغلب المدن إقليم ؤردستان. الكلمات الدالة: الأحياء القدية، الاسر الحضري، مساكن الإيواء المؤقت، المساكن والمناطق الشعبية، النسيج العمراني للمدينة

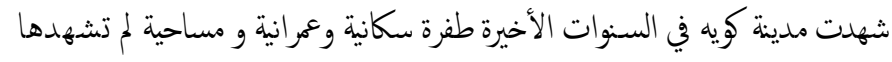

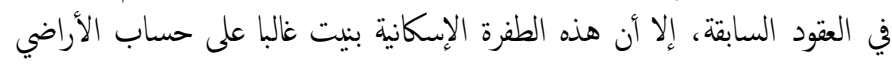

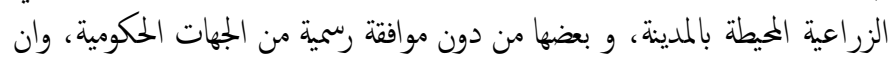

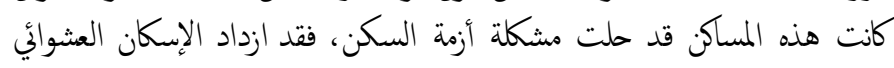

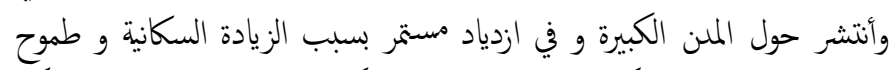

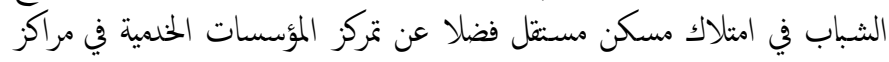

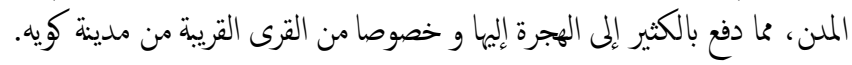

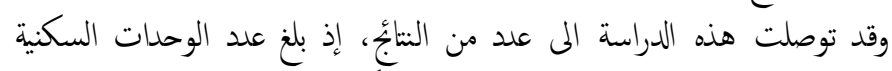

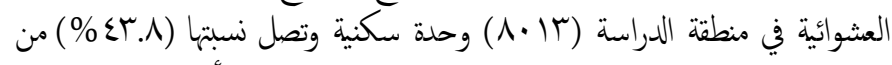

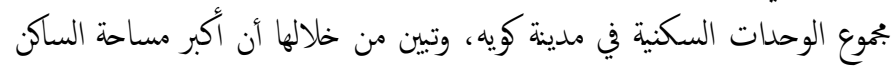

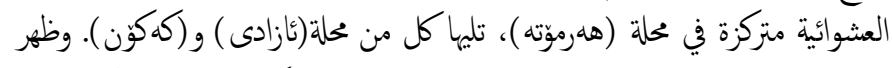

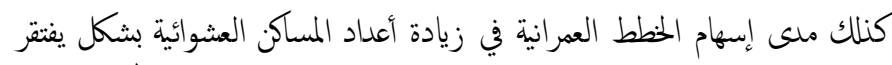

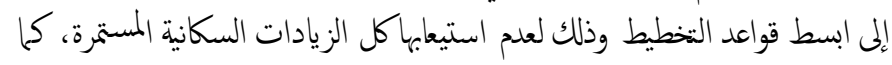

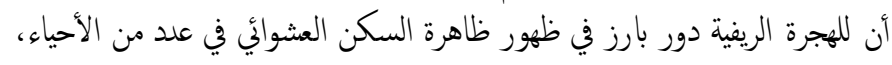

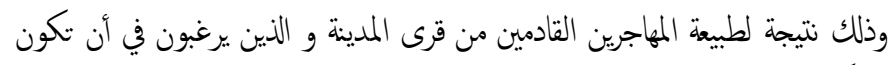

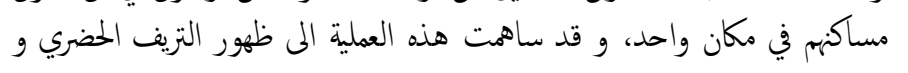

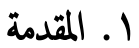

السكن العشوائي من المشاكل الحضرية التي تعاني أكثر دول العالم و بالأخص الدول

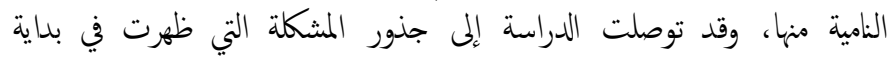

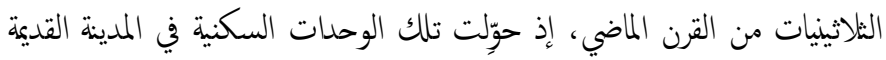

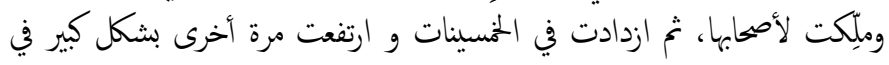

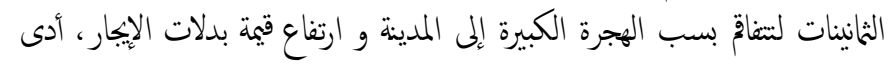

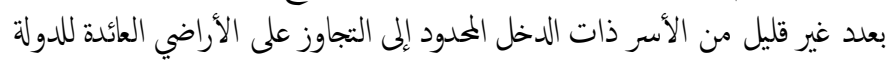

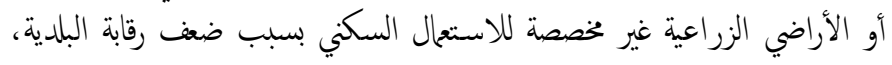

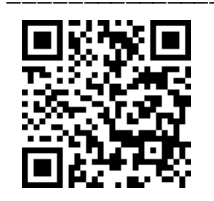

مجلة جامعة كويه للعلوم الإنسانية والاجتماعية

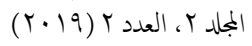

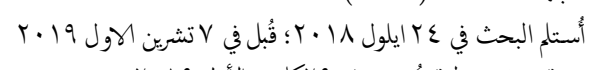

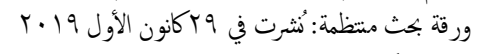
البريد الإلكتروني للمؤلف: kameran.taher@koyauniversity.org

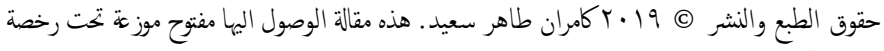

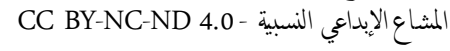


شهالا، وبين خطى طول (ع乏،

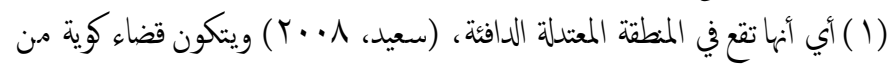

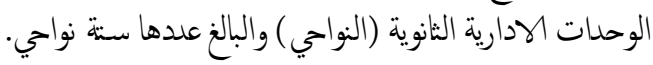

\section{r ـ مفهوم السكن العشوائي وانماطه، وبعض المصطلحات ذات الصلة}

بالموضوع

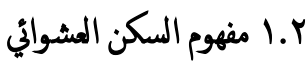

مفهوم السكن العشوائي وتعريفه يختلف من مكان إلى آخر ومن دولة الى أخرى،

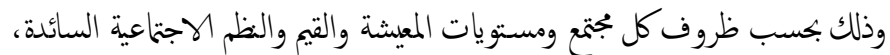

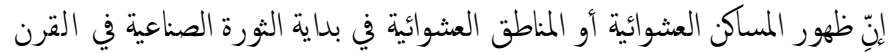

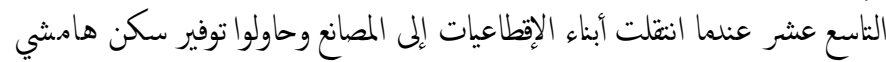

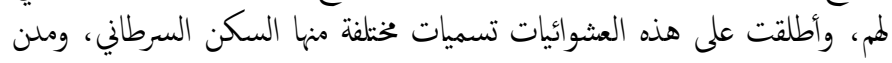

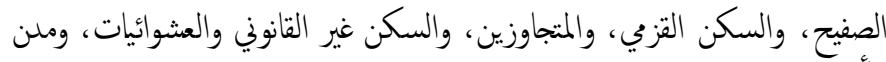

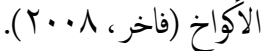

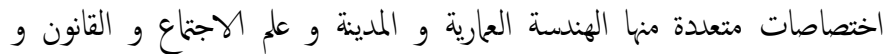

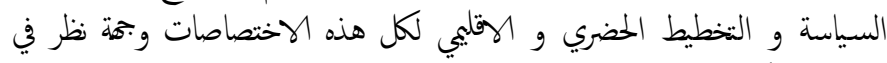

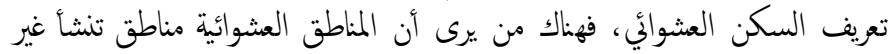

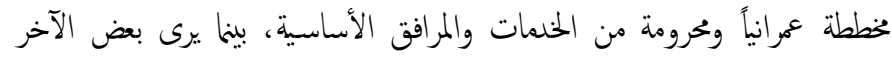

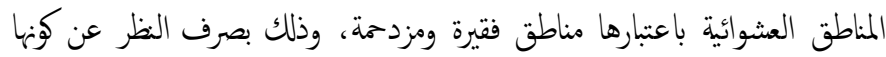

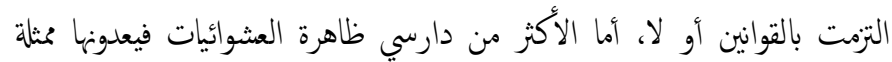

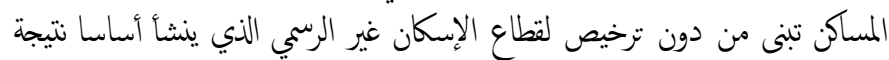

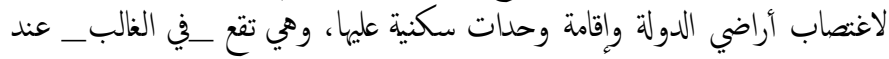

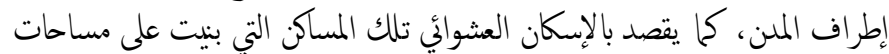

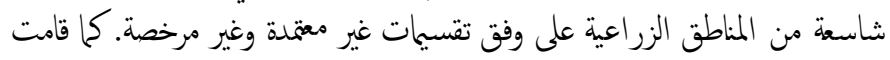

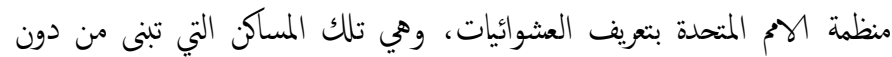

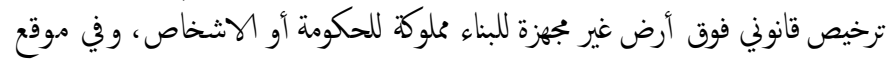

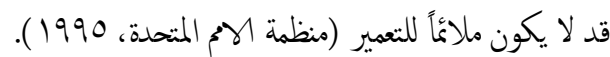

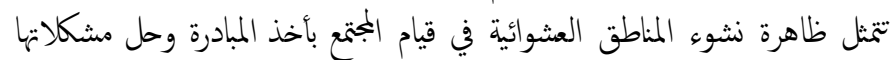

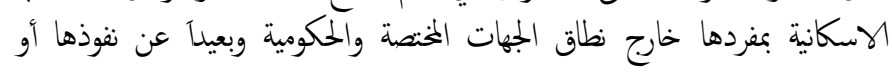

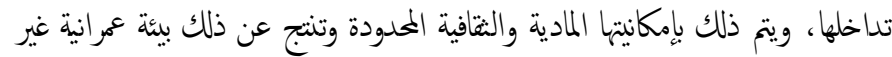
مقبولة من كلة النواحي حيث ينقصها الكثير من القيم والمبادئ العحارية والبيئية

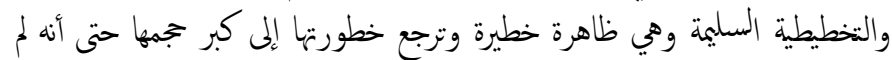

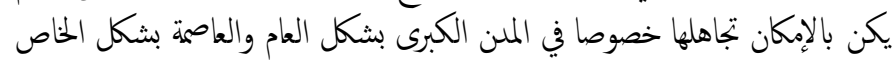

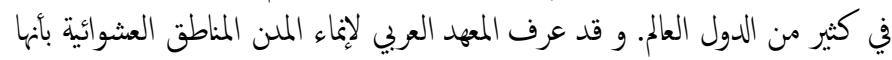

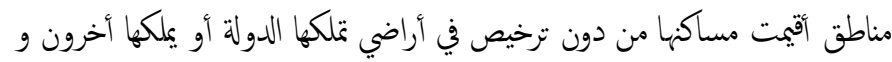

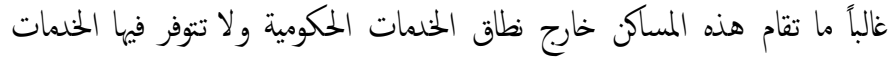

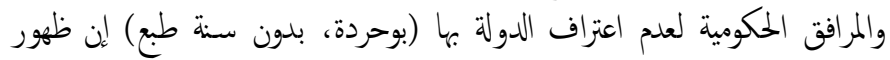

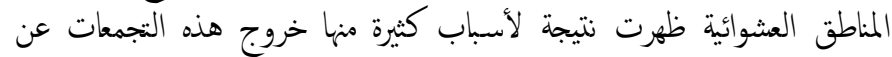

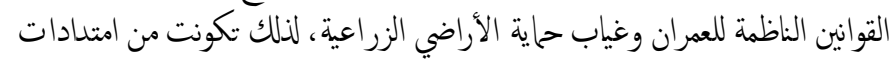

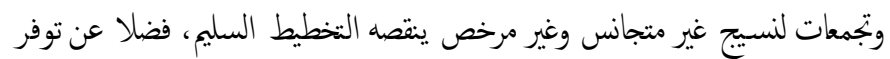

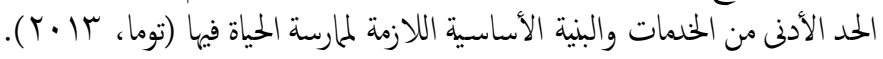

خير مثنال لهذه الظاهرة في محلة شهوكيراوه، وهناك عدة أسباب تؤدي إلى التجاه

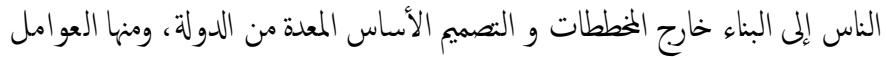
(الديوغرافية التخطيطية والتشريعية السياسية و الاقتصادية و الاجنتاعية).

1 ـ هدف الدراسة

يبرز هدف الدراسة كهها تتناول بالدراسة والتحليل ظاهرة السكن العشوائي في مدينة

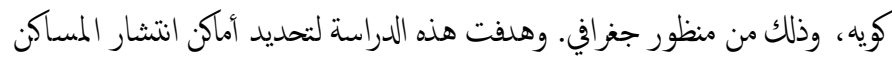

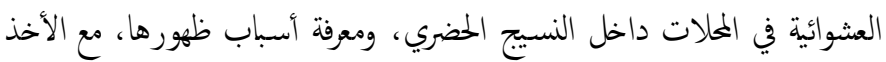

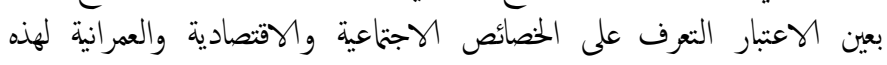

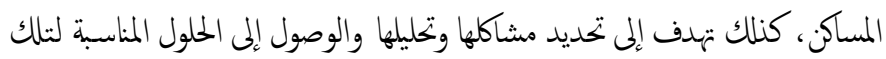

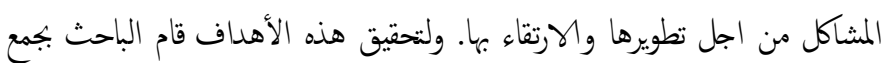

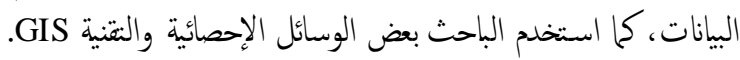

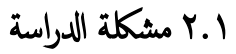

تعد العشوائيات على اختلاف أنواعه من المشكلات الكبيرة التي تواجه مدينة كويه

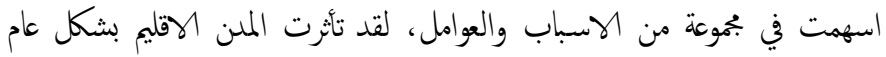

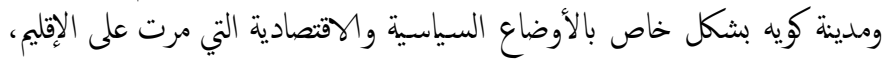

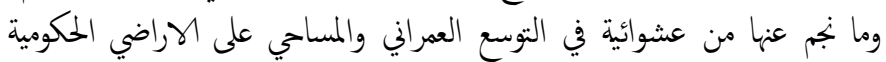

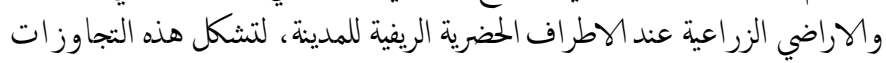

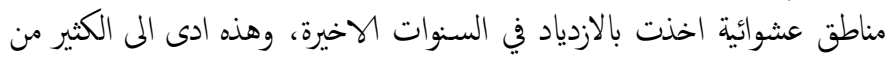

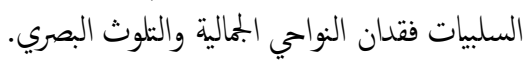

ا ب. ب منهجية الدراسة

وقد استخلمت في الدراسة المنهج الوصني النحليلي- التزكيب لدراسة كل النواحي

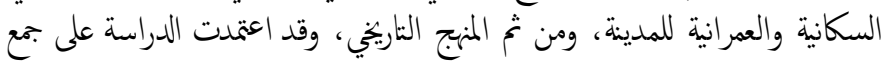

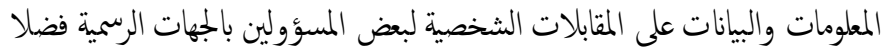

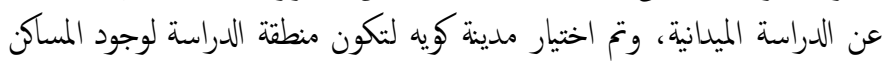

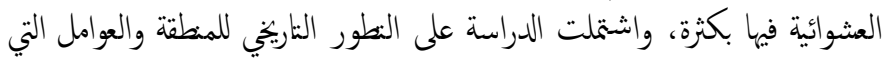
ساعدت على قيامه.

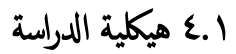

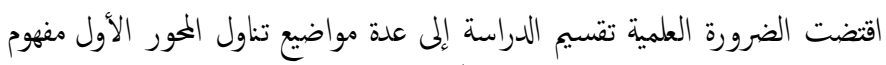

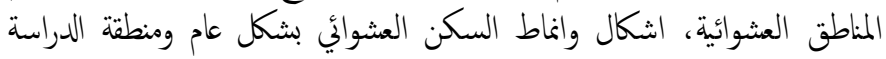

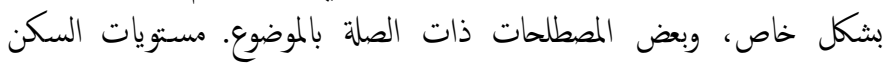

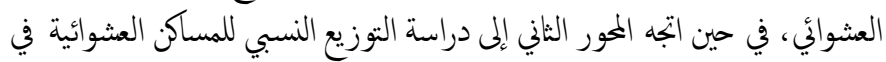

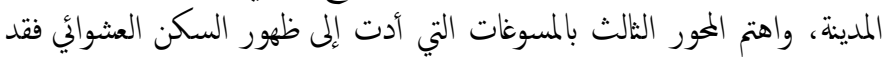

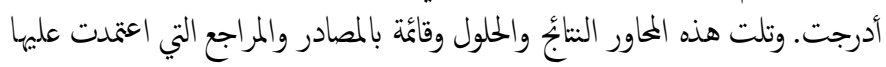
الدراسة.

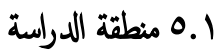

تمثلت حدود الدراسة بمدينة كويه مركز قضاء كويسنجق التي تقع في القسم الجنوبي

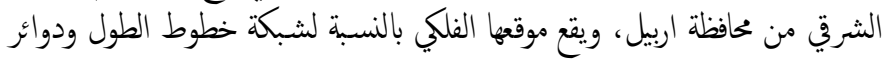

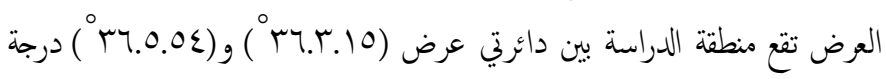




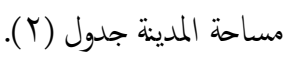
أما مساكن الإيواء الموقت حيث توجد ماعد مساحة صغيرة في المدينة، وخصوصا بعد ظهور

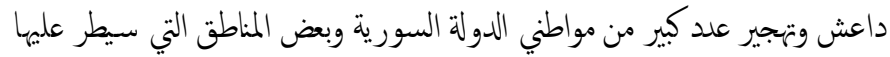

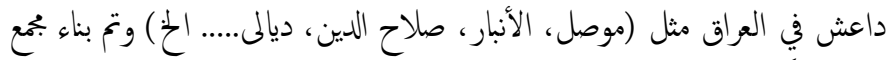

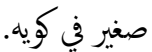

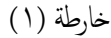

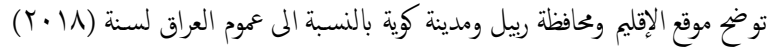

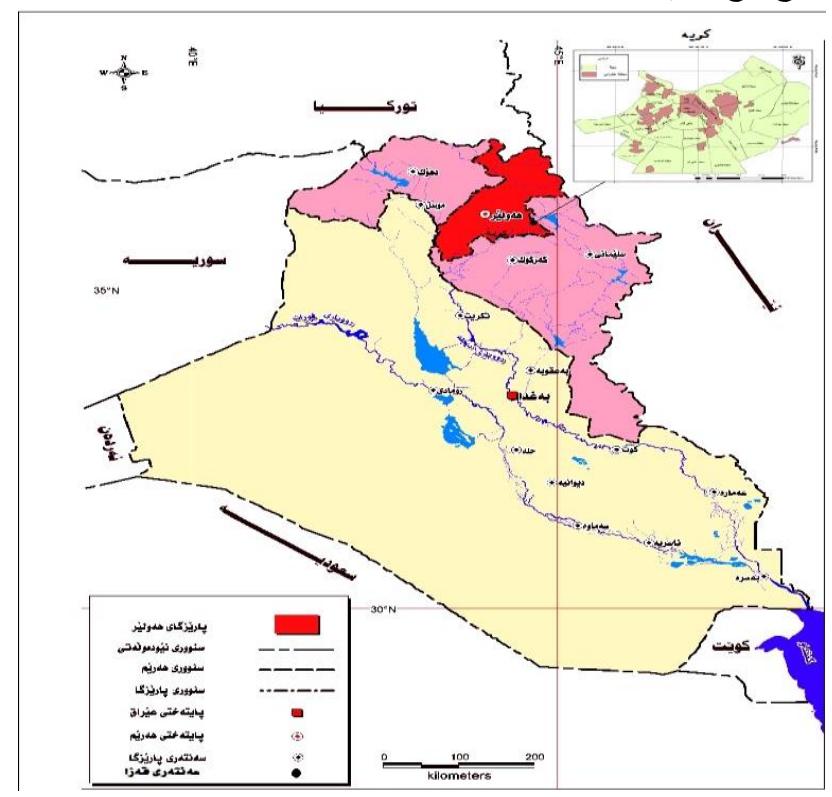

المصدر: إقليم كوردستان العراق، وزارة البلديات والسياحة، مديرية التخطيط العمراني، قسم GIS

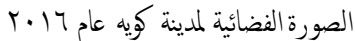

المجموعة الثانة: المناطق التي نمث بعرفة الأهالي المناطق غير الرسيمة:

وتندرج تحت هذه المجموعة:

ا. الجيوب الريفية وسط النجمعات الحضرية أي عملية الاسر الحضري أو من دون

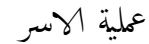

r. مناطق الزحف على الأراضي الزراعية

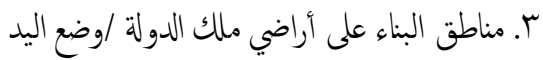

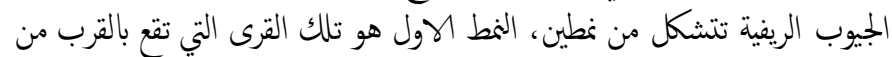

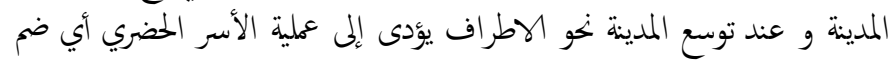

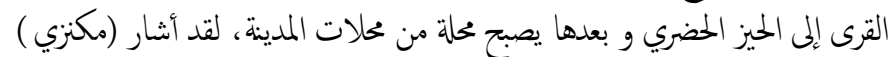

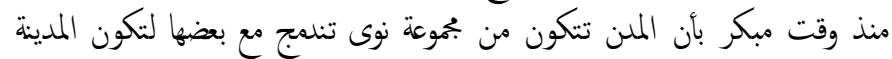

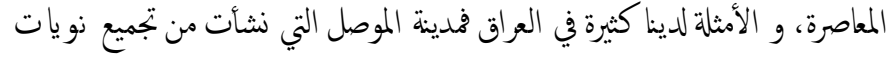

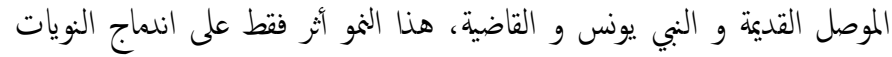

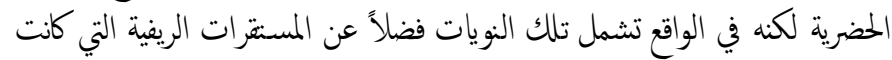

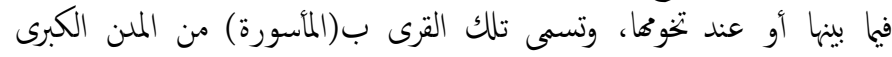

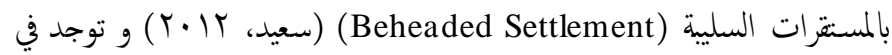

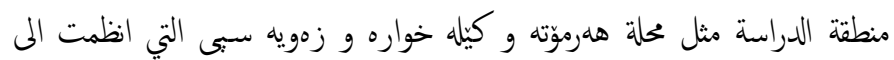
مدينة كية في المرحلة المورفولوجية الرابعة 3

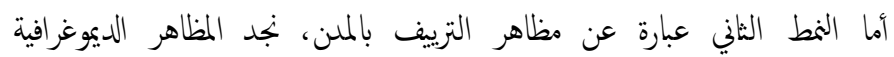

هناك تعريف قانوني للعشوائيات السكنية فهي تلك المناطق التي لاييوز البناء عليها

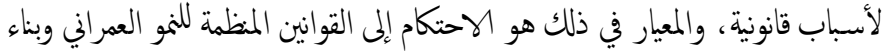

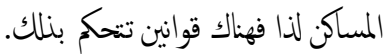
أو هي تلك المناطق التي تضم كل المساكن التي اقيمت مخالفة لقوانين التظيم المعمول

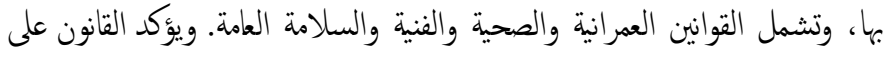

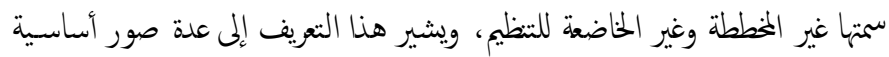

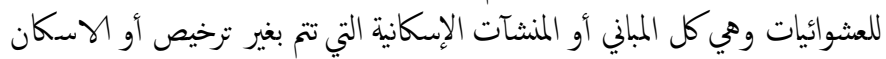

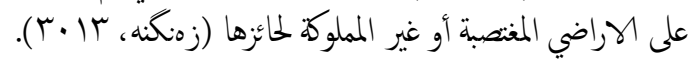

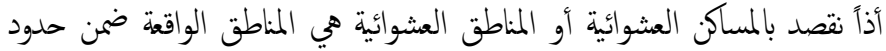

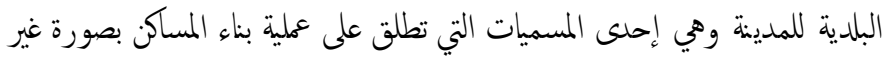

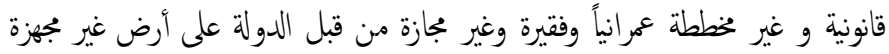

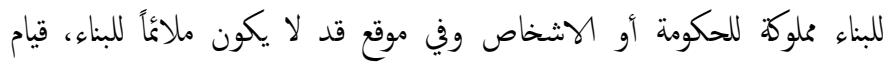

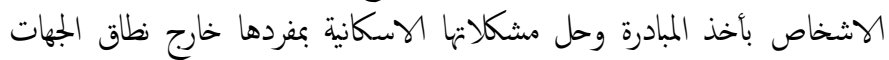

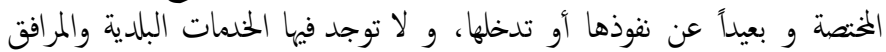

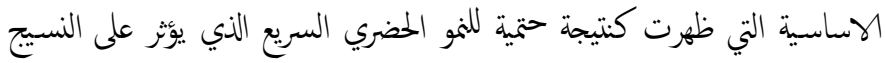
الحضري للمدينة.

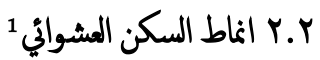

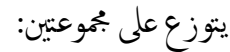
الجمموعة الأولى: المناطق التي انثأت بمعرفة الأجزة الحكومية أو المباني المرخصة:

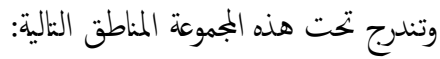
ا ـ المحلات والأحياء القديمة r. المسآكن والمناطق الشعبية

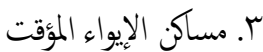

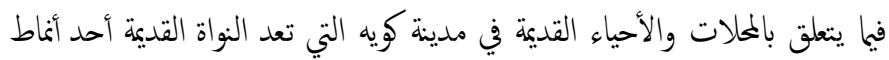

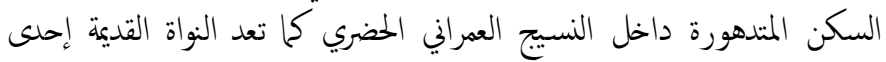

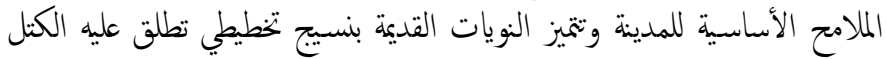

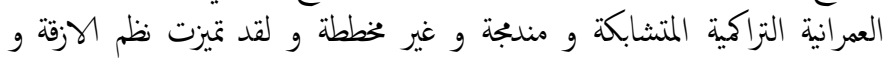

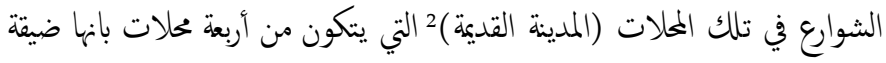

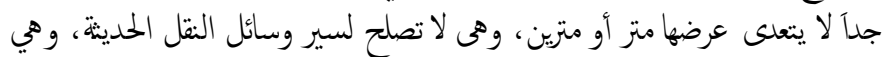

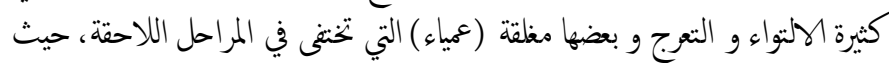

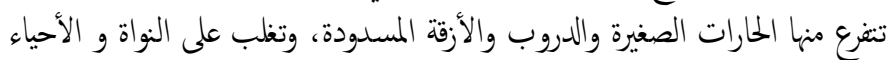

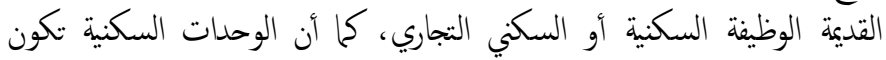

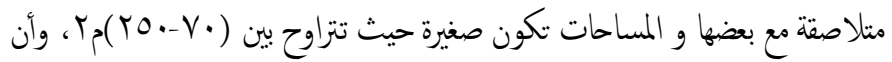

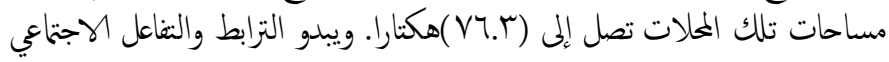

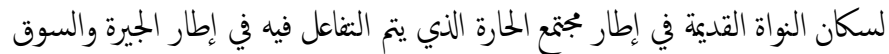

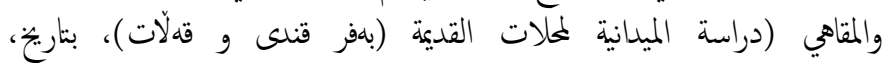

. $(r \cdot \mid N / T / 1 T$

والمساكن والمناطق الشعبية التي تضم قطاعاً كيرا من المناطق العشوائية السكنية

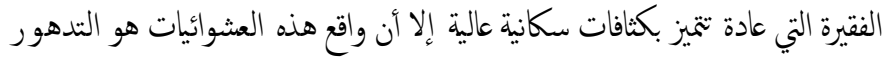

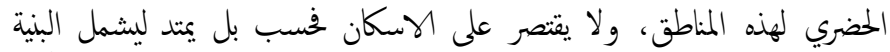

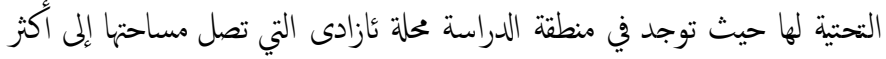

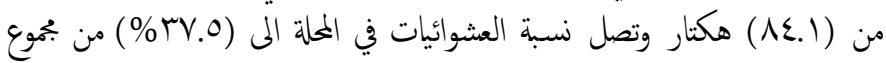


و ما يترتب على وجود هذا من اثار على الأمن و الأخلاق ، كما آن هناك تعريفاً آخر

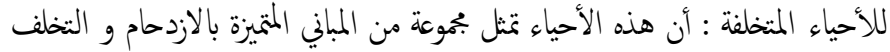

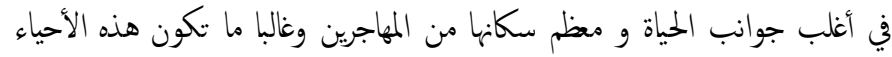

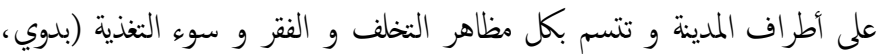

بدون سنة طبع). الحي المتخلف يسمى بعض الاحيان بالحي العال، كما فسرت ظاهرة الحي المتخلف في

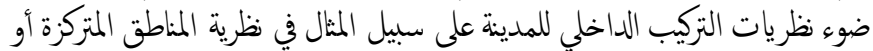

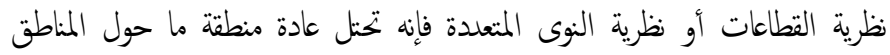

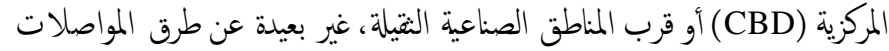

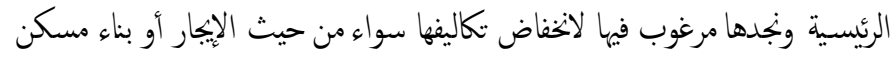

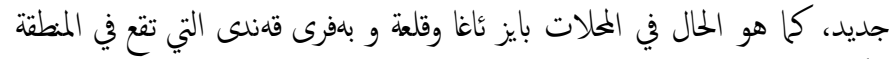
المركزية من منطقة الدراسة. التوسع الممراني

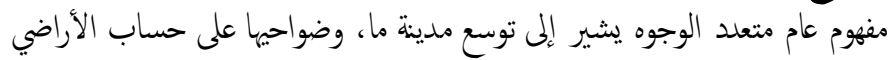

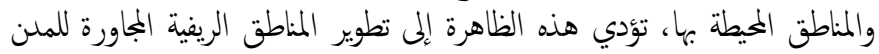

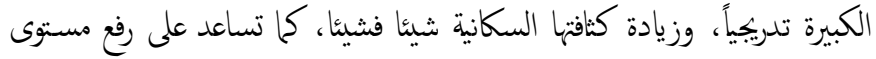

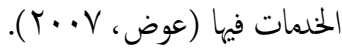

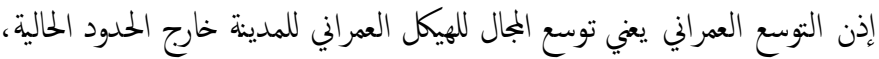

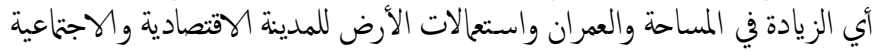
والعمراني. إن نمو المدن وتوسعها ظاهرة حضارية ترتبط بعدة متغيرات بعضها له علاقة بمو المدينة

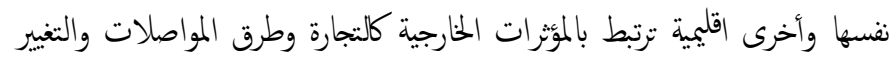

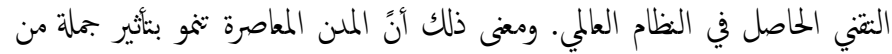

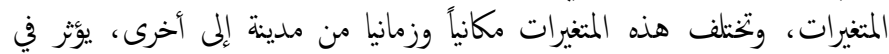

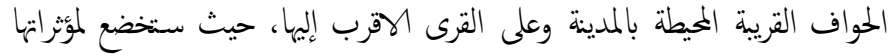

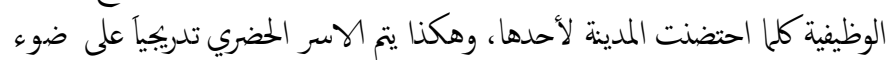
الهمكانات الجغرافية المتاحة لتوسع المدينة أفنياً.

خطة المدية City Plan

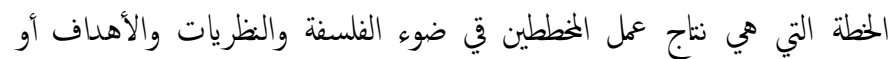
التوجحات نخو تحقيق إنجازات مادية محلدة وملموسة من حياة الناس تعرف بخطة

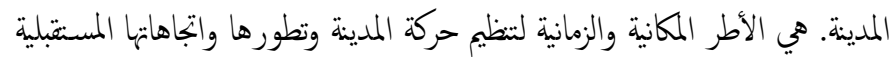

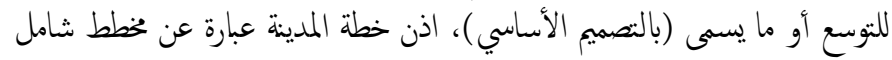

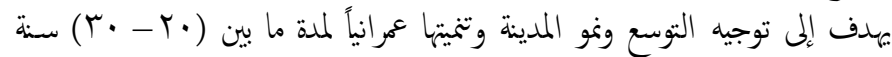

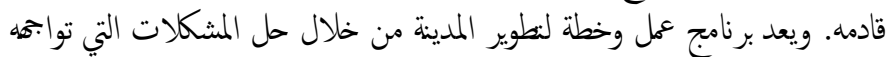

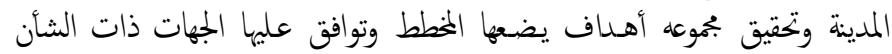

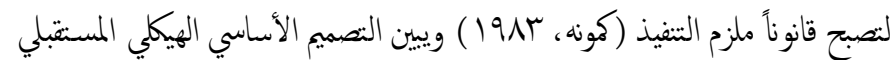

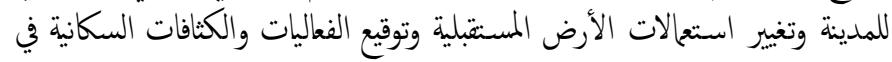

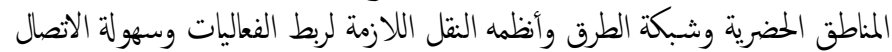

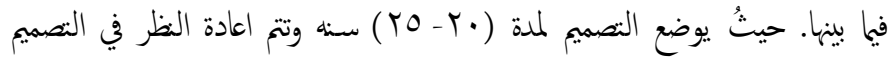

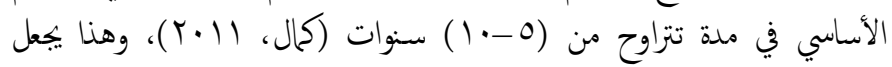

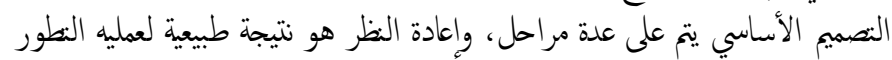

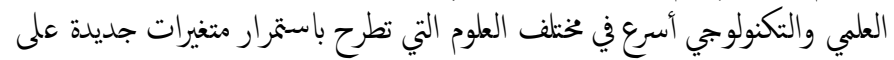

والاجتماعية وتتجلى في تضخم عدد السكان واحتفاظ السكان المنحدرين من الأرياف

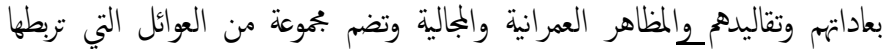

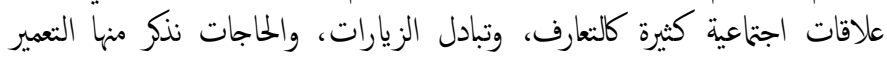

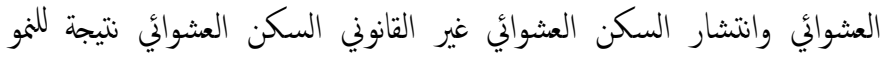

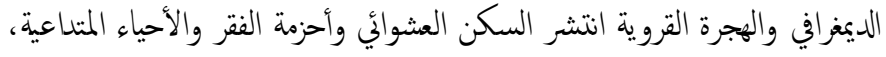

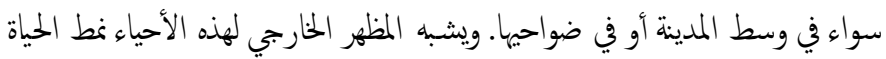

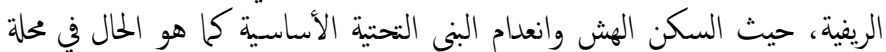
شهوكيراوه.

ومناطق الزحف العراني على الاراضي الزراعية عندا تتوسع المدينة على ضواحهيا

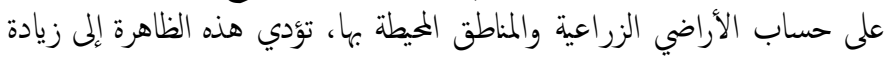

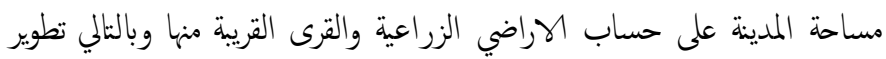

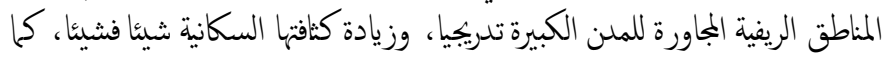

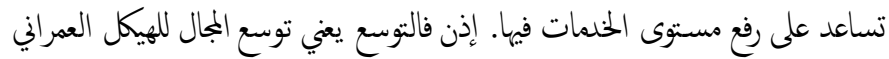

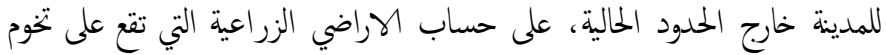

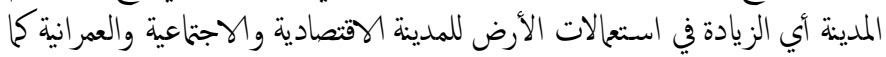

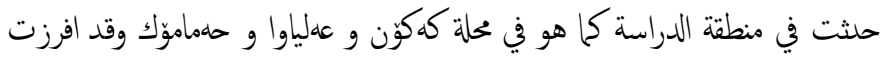
هذه الظاهرة أزمات متعلدة في مجال خلمة المات فئ المختلفة.

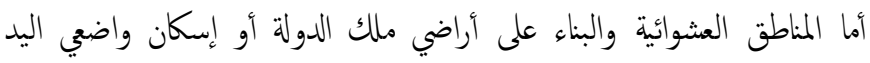

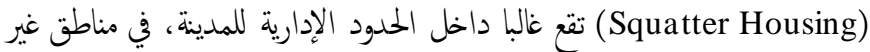

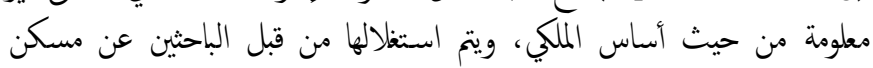

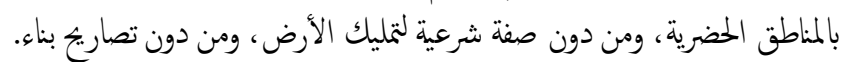

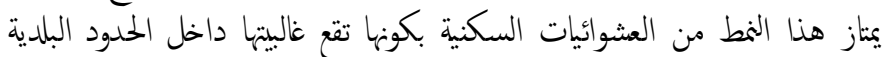

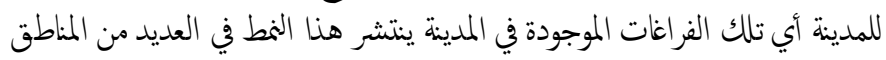

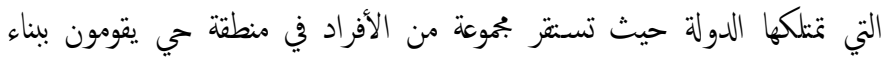

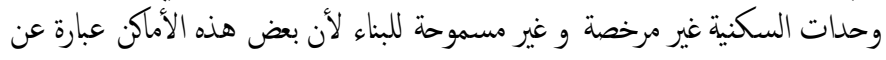

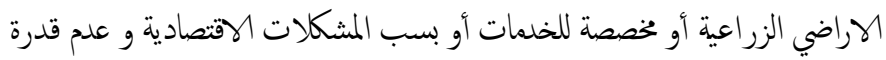

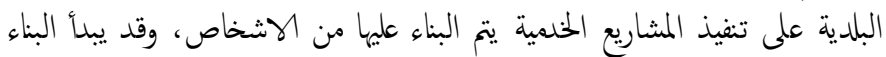

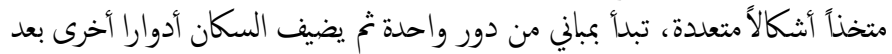

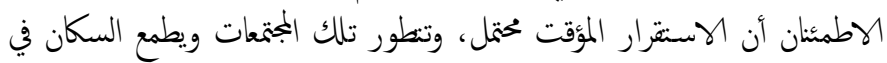

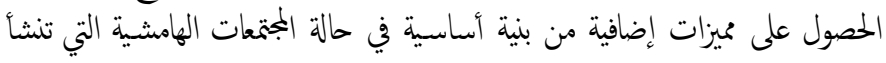

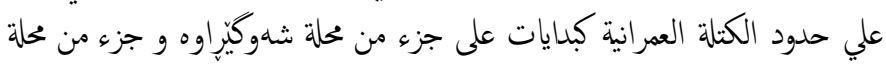

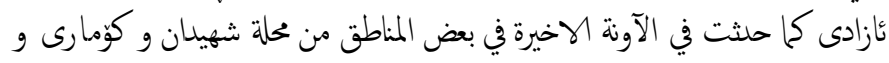

$$
\text { قهنديل و غيرها. }
$$

\section{r.Y تعريف بعض المصطلحات ذات صلة بالمساكن المشوائة}

Old Neighborhoods الوحياء المتخلفة المناء

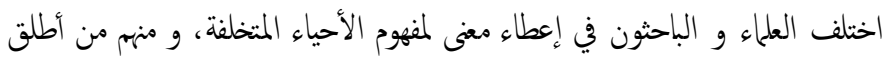

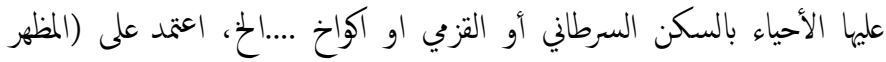

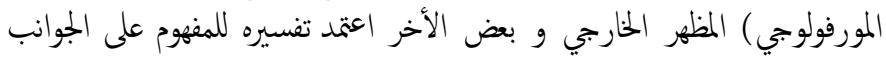

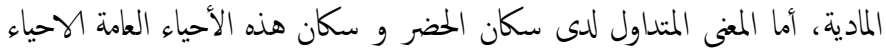

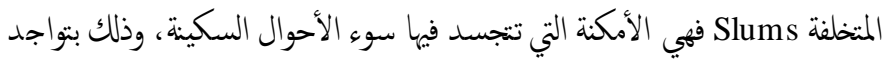

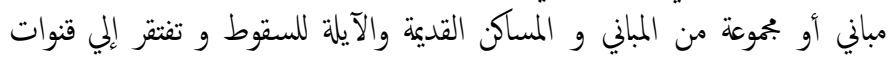
الصرف الصحي وتتسم بالازدحام الشديدو التخلف و الظروف المُ الصحية غير الملائمة 
الاتجاهات المكانية لمقظم مدن العراق بما فيها مدينة كويه هي توبحات أفقية بكثة،

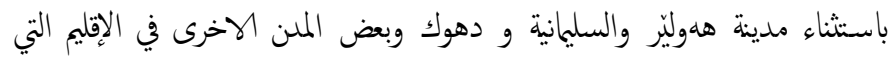
اعتمدت بعض الشيء البناء العمودي.

\section{r.1. البعد التاريخي للسكن المشوائي في مدية كويه}

إنَّ شكل الزحف العمراني الحضري للعديد من المدن آفة حضرية من نوع جديد تلنهم

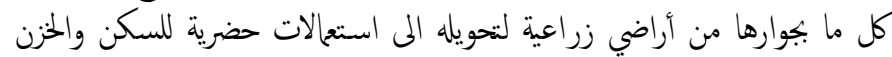

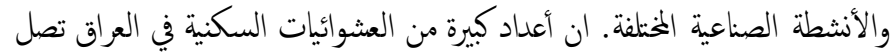

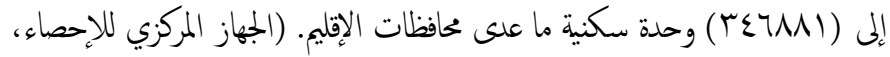

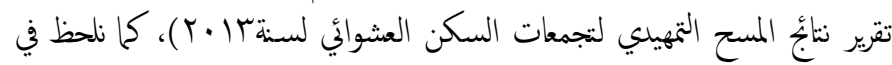

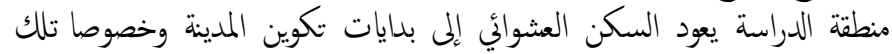

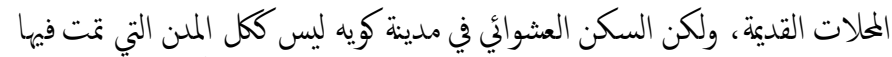

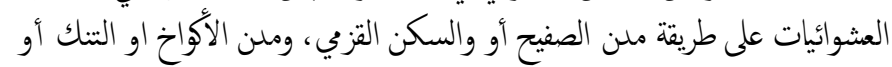

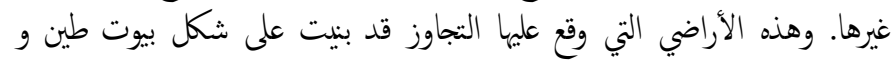

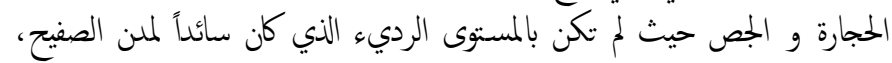

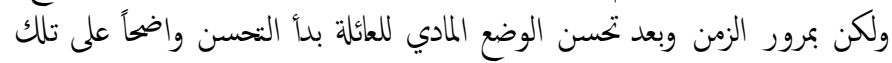

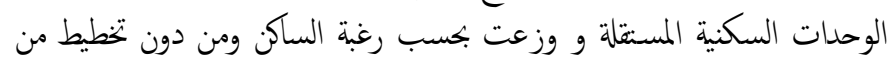

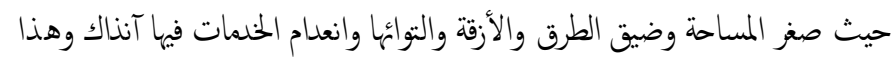

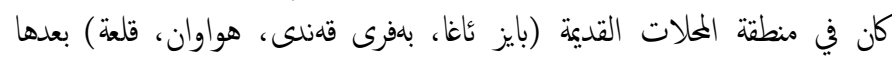

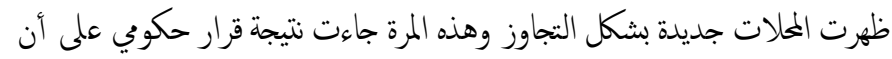

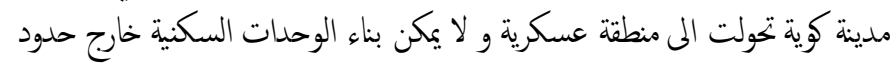

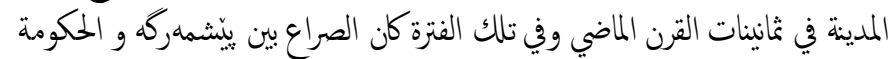

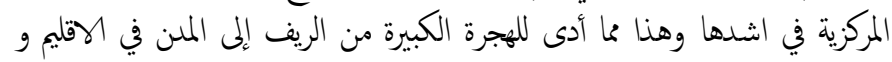

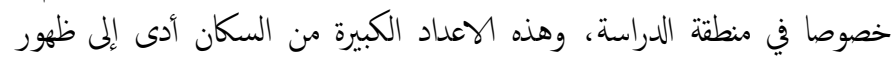

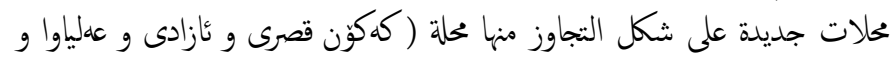
حلمامؤك و شهوكيراوه).

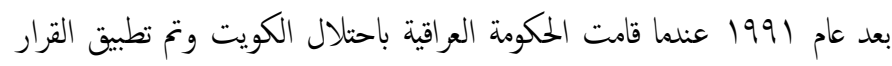

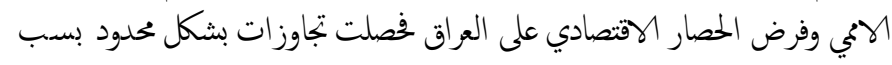

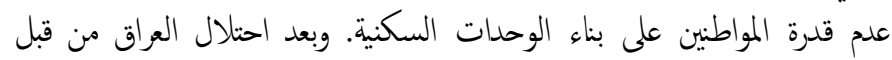

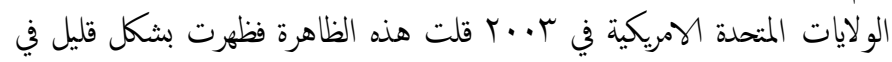

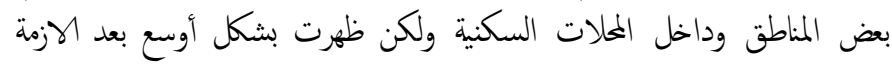

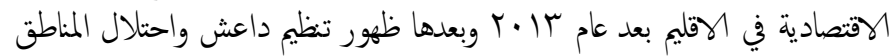

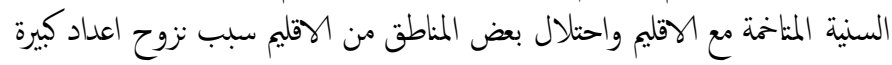

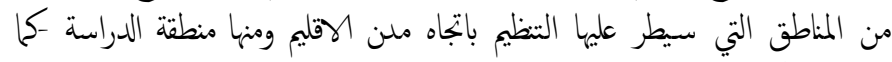

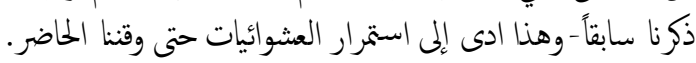

\section{r.r r.r اقع المناطق العشوائة ضمن حدود الثصميم الأساس للمدية}

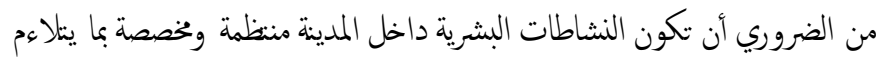

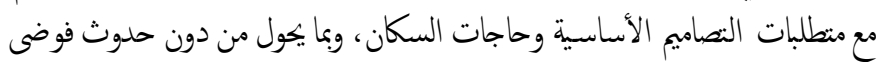

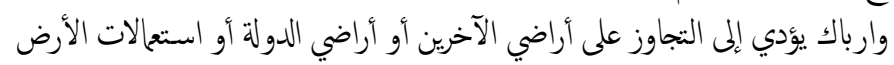

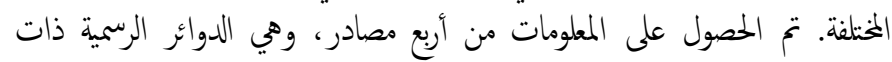

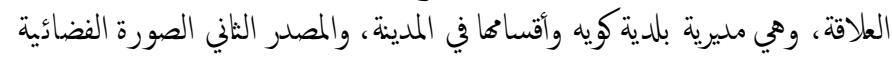

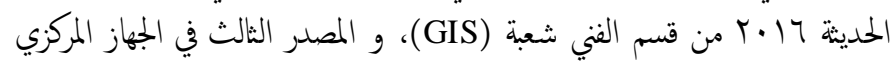

مجتمعات المبن. وكنلك بسبب متغيرات نمو حجم السكان وتلبية المططلبات الجديدة

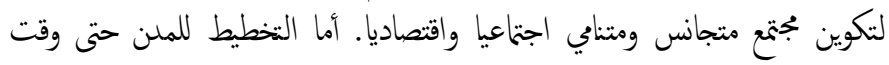

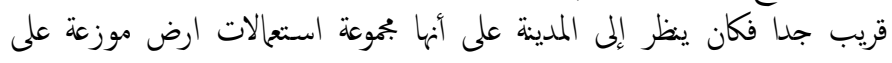

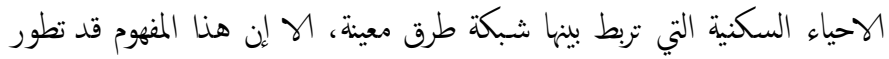

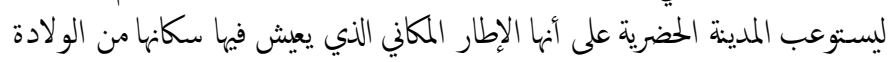

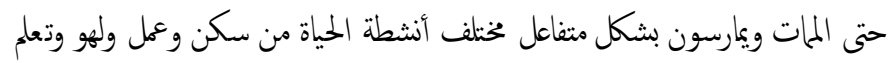

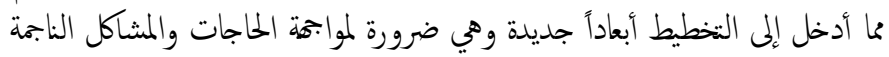

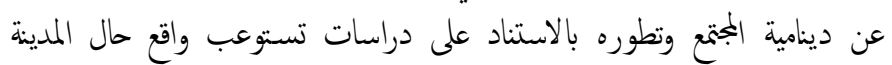

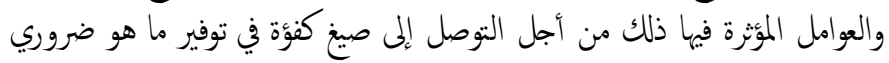

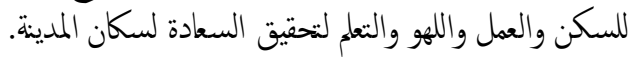

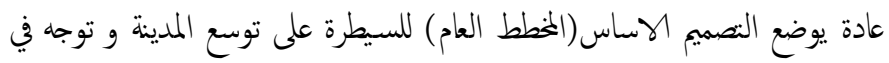

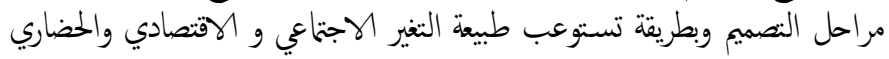

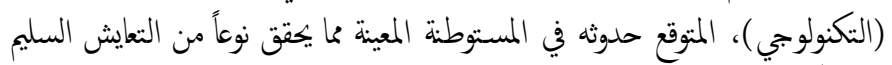

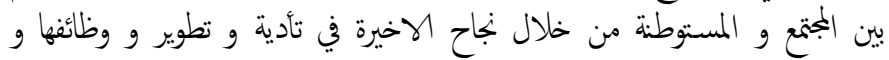

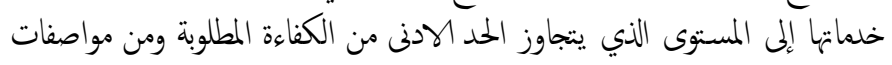

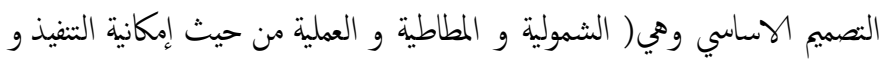

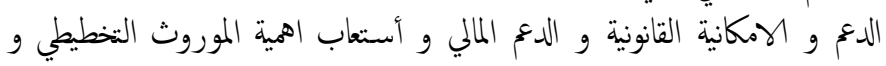

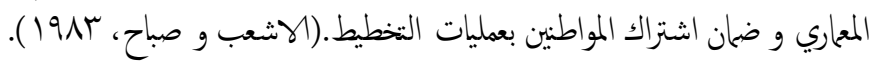

\section{Urban Capture الاسر الحضري}

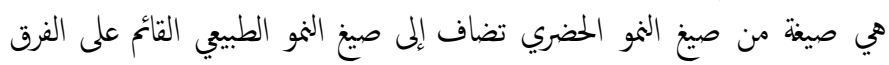

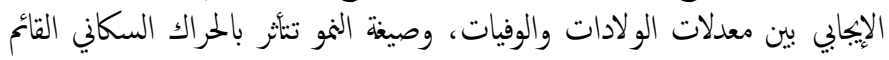

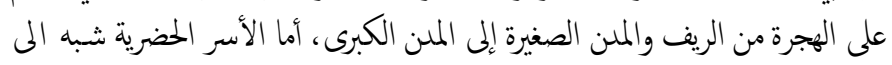

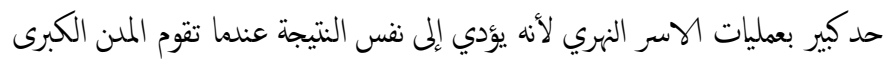

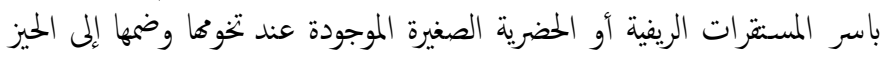

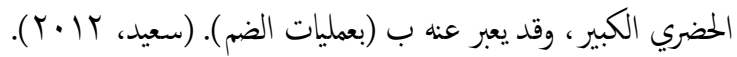

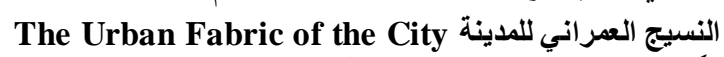

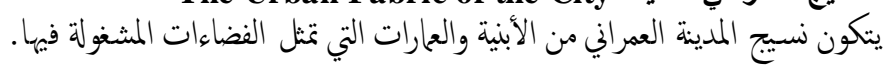

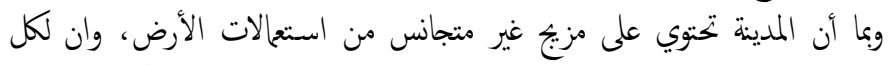

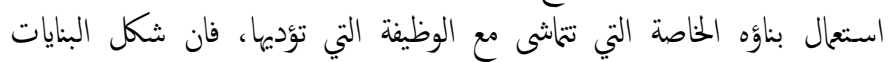

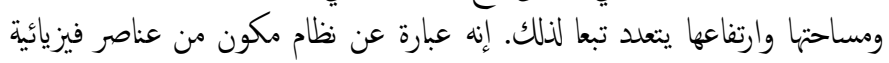

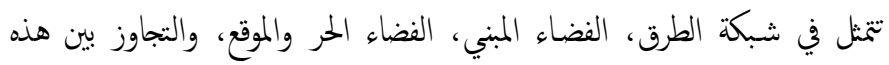

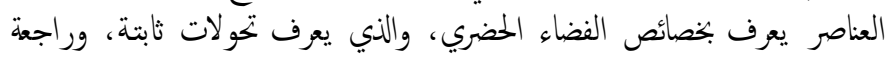
للنطور الذي تتعرض له هذه العناصر المكونة له عبر مرور الزمن (الشيباني، 1990)

\section{r. التوزيع النسبي للمساكن العشوائية في مدينة كويه}

من الضروري أن تكون النشاطات البشرية داخل المدينة منظمة ومخصصة بما يتلاءم

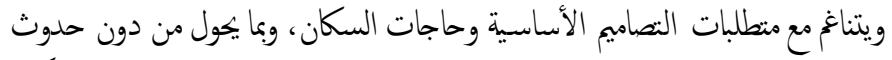

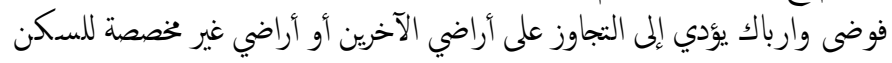

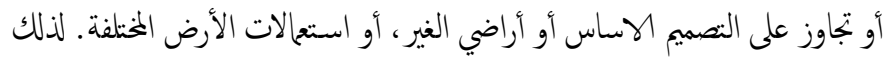

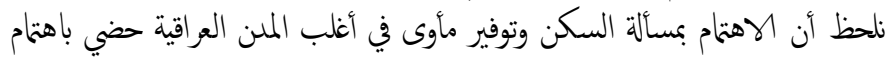

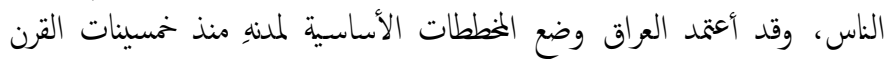

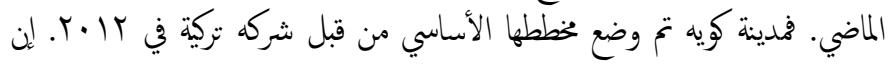


وفي ثمانينيات القرن الماضي تم تسجيل منطقة عأزادى و حهمامؤك وغيرها من المحلات

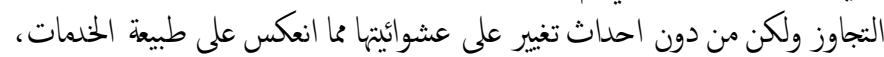

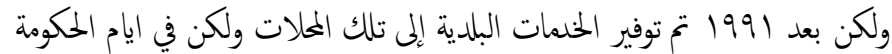

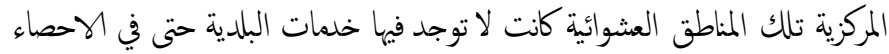

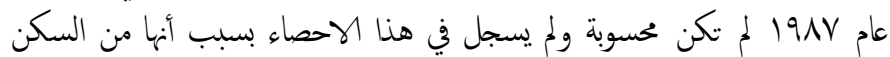

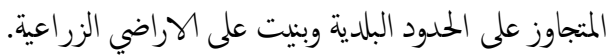

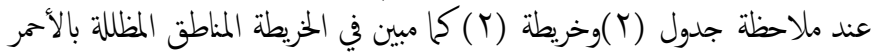

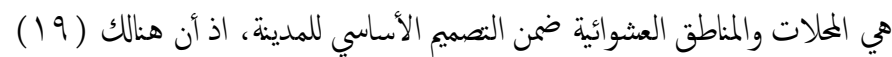

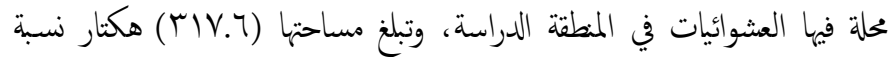

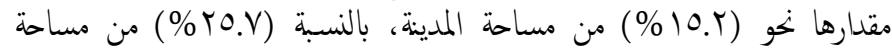

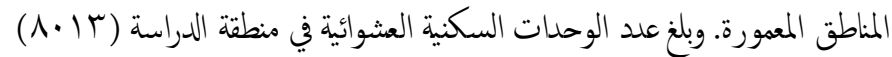

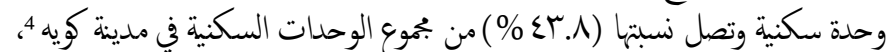

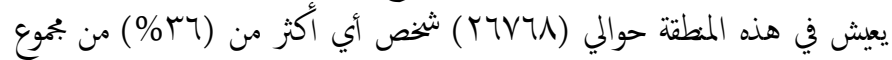

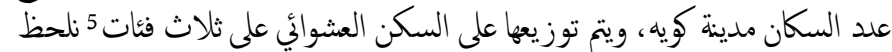

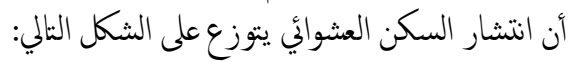
الفئة الأولى: وهي المحلات التي فهيا مساحة كيرة من السكن العشوائي التي تصل مساحتها اكثر من كن كنان

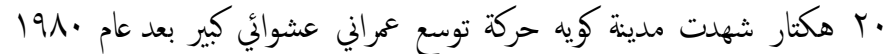

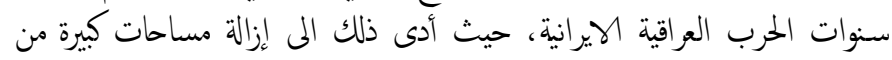

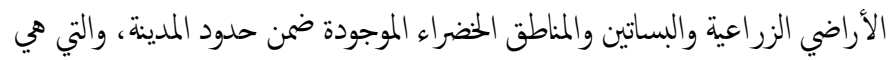

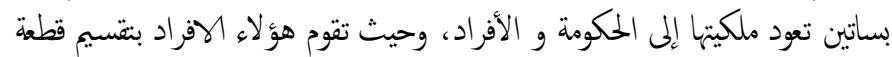

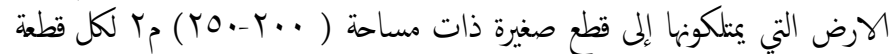

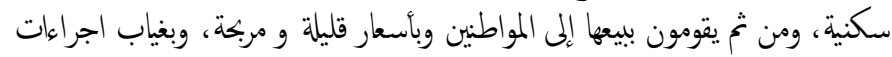

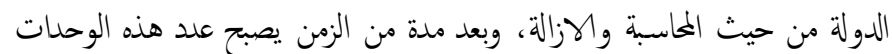

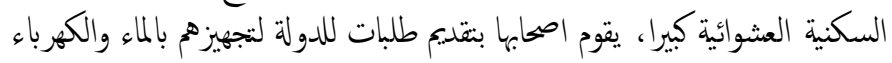

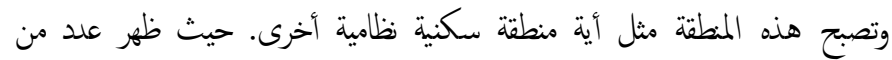

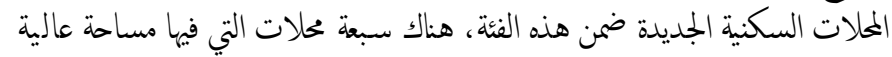

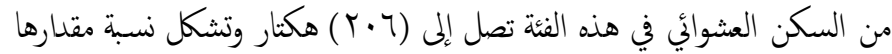

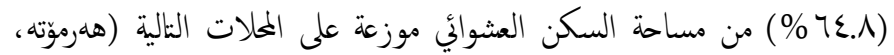

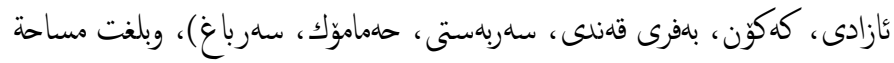

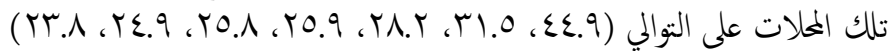

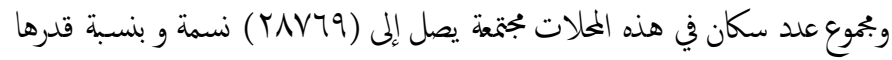

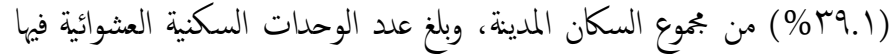

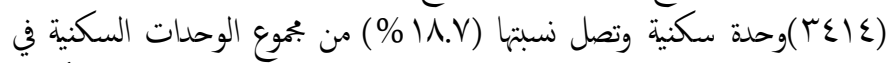

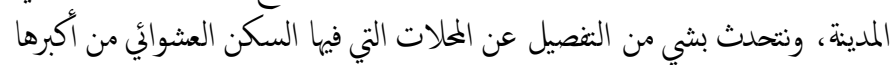
مساحة إلى أصغرها مساحة بصورة متسلسلة على نحو الاتئ:

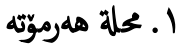

وظهرت في هذه المحلة أعلى مساحة من السكن العشوائي في هذه الفيئة والمدينة التي

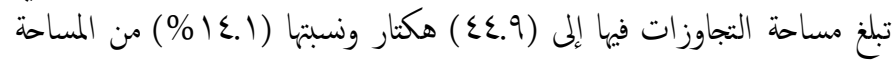

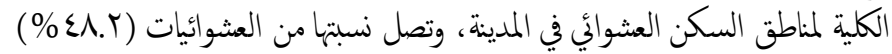

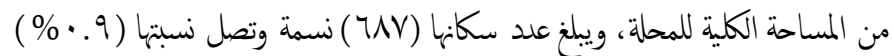

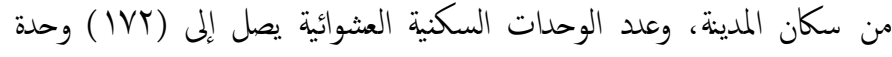

للإحصاء في مدينة كويه التابع لوزارة التخطيط للإقليم، و المصدر الاخير المسح

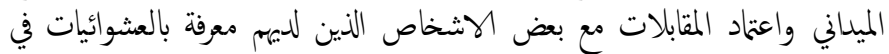

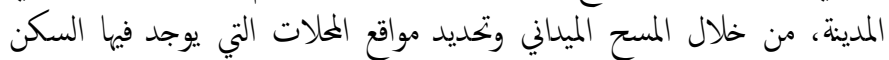

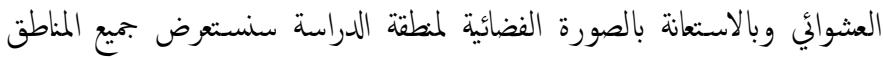

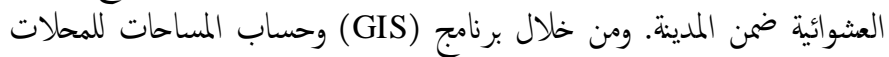

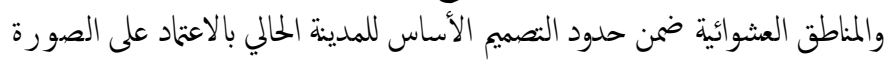
الفضائية لمنطقة الدراسة.

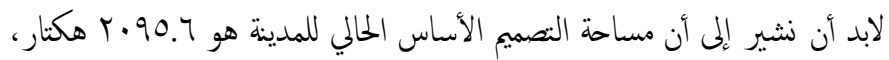

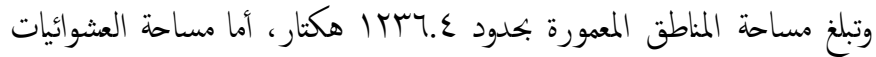

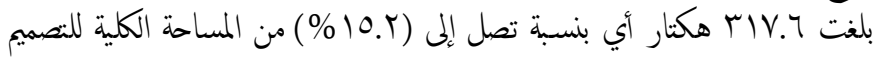

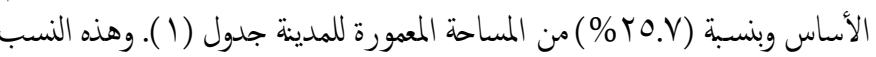

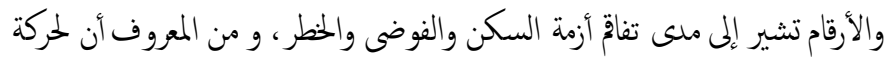

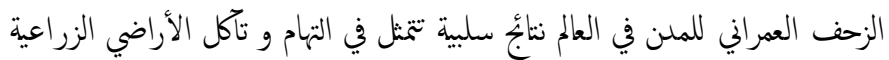

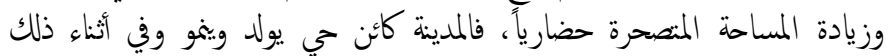

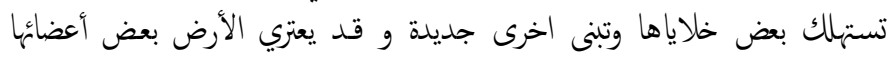

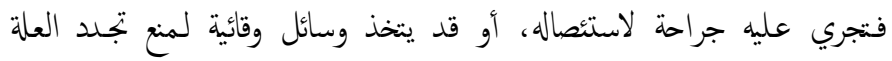

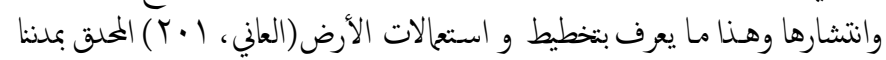

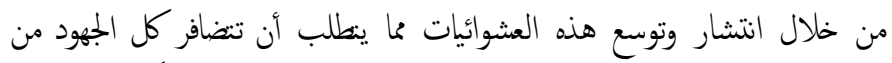

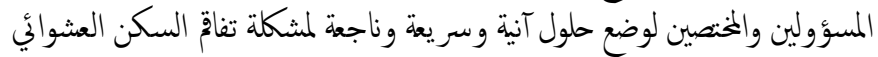

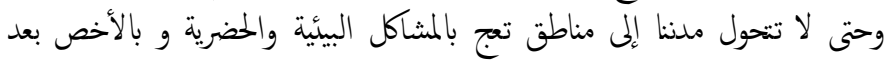

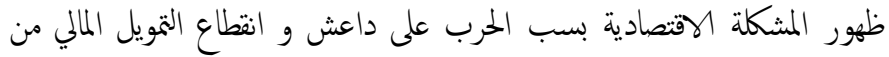

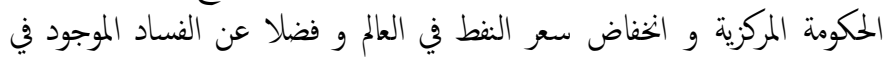

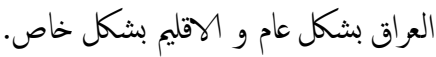

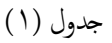

المساحة الكلية للتصميم الأساس والمساحة المعوورة ومساحة مناطق السكن العشوائي ونسبتها المئوية

\begin{tabular}{|c|c|c|c|}
\hline العشوائي & مساحة المناطق السكن & 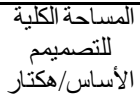 & نوع الاستعمال \\
\hline $10 . r$ & TIV.T & $r .90 .7$ & التصميم الأساس \\
\hline ro.Y & TIV.T & KTY. & المعناطقة \\
\hline
\end{tabular}

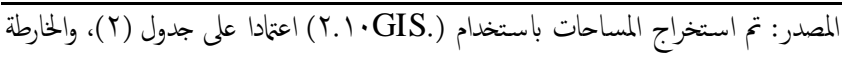
الفضائية لمدينة كويه.

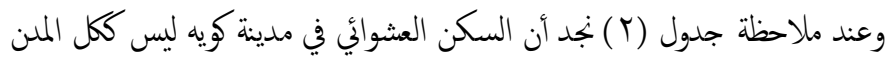

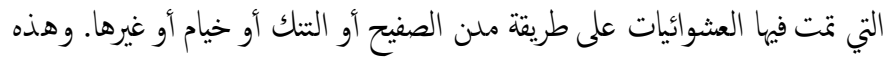

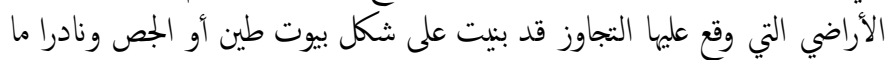

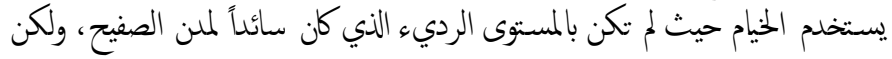

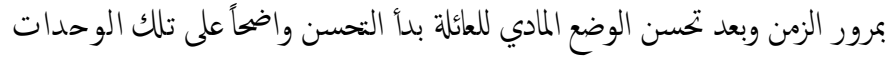

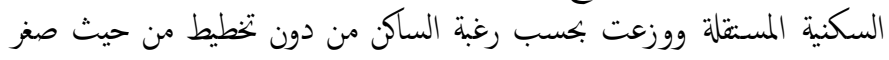

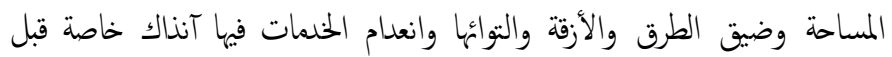
الانتفاضة عام 1991 وكان هنا في المحلات قصرى، ئازادى، كةكؤن و حهمامؤك.. 


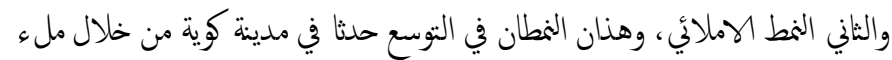

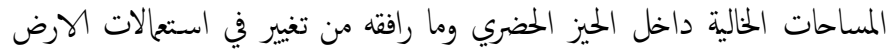

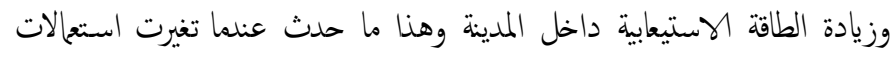

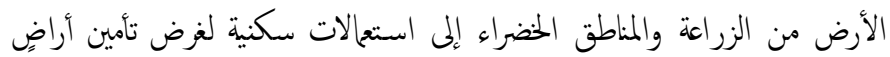

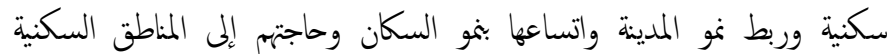

$$
\text { والخنمية وغيرها. }
$$

ه . محالة سلربهستى وعرها.

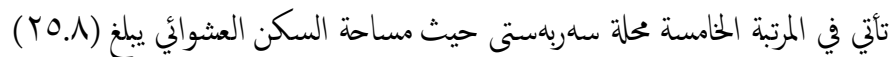

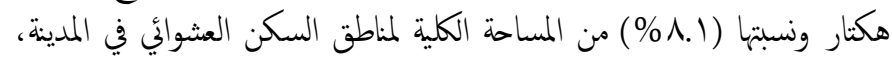

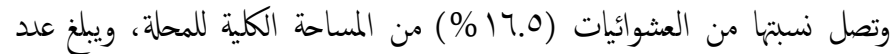

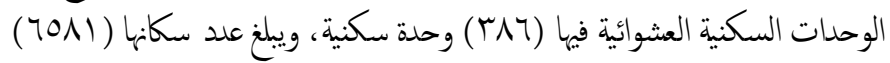

جدول (Y)

عدد المحلات والنفوس والوحدات السكنية العشوائية والمساحات العشوائية ونسبتهم في المحلة وفي

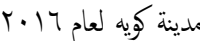

\begin{tabular}{|c|c|c|c|c|c|c|}
\hline العشو ائية من احنة & العشوائيةً & العشاحة المناطق & الوحدمات & عدد النفوس & هكتار المسة/ & المحلة \\
\hline 91.1 & r.. 9 & rาqr & $\varepsilon+1$ & 1774 & r9.0 & بهفرى قهندى \\
\hline $7 \leqslant .7$ & $1 v .9$ & IV9นтT.7 & $7 \leqslant 1$ & TIKV & $r V . \wedge$ & لقلعة \\
\hline or.o & 17.1 & $17.700 . \mathrm{V}$ & ২৯৭ & $1 \leqslant T r$ & $r \cdot .7$ & بايززاغا \\
\hline$r \cdot r$ & r.V & r.q1r.r & $1 \pi \varepsilon$ & $\wedge 1 \wedge$ & IT. & جوارباخ \\
\hline vq & ה. & rrVqqะ.q & $\leq 9$. & $r 1 .$. & $r \cdot .1$ & سلرباغ \\
\hline---- & --- & ---- & ---- & $1 \leq r$ & $101 . \mathrm{r}$ & هو اوان \\
\hline$r v .0$ & $r 1.0$ & r1010r.r & 1.10 & $\wedge \| \wedge$ & $\wedge \leq .1$ & ئاز ادى \\
\hline rV.O & $\varepsilon .0$ & $\varepsilon 0194 . r$ & IrT & $7 \leq 0$ & 17.0 & خمر مان سو تاى \\
\hline $7 . \varepsilon$ & $v_{.} \varepsilon$ & VMT.Y.V & IrA & $\varepsilon r 1$ & $11 \leq .9$ & كانى قعره \\
\hline---- & --- & ---- & ---- & $r \leq T$ & 71.9 & جوارجرا \\
\hline ov.r & $r \leqslant . \wedge$ & $r \leq \vee q \vee \wedge .1$ & 071 & ५А१৭ & $\varepsilon r . \varepsilon$ & حماموّك ك \\
\hline---- & ---- & ---- & ---- & $r \leqslant r q$ & or. & حاجي قادر \\
\hline 11.1 & V.r & VYTOY.r & $r \leqslant r$ & TrTt & $\varepsilon \cdot .1$ & : لَّدار \\
\hline r.l & 17.1 & ITVVTO. & $\Lambda \leqslant \vee$ & r910 & or.r & بـابهرِين \\
\hline$\varepsilon . V$ & 0.1 & $0 \wedge \leqslant 70.0$ & $1 \leqslant 9$ & 117 & $1 r \leq$ & زمويه سبىى \\
\hline---- & --- & ---- & --- & Errq & $T \leq . \wedge$ & زانست \\
\hline 7. & r. & M M & lor & $\Lambda \leqslant V T$ & $\leq 9.9$ & كوّمارى \\
\hline r.^ & r. & TVTrA. & $v \wedge$ & $1 \leqslant \wedge \leqslant$ & Irt. 9 & قهنديل \\
\hline --- & ---- & --- & ---- & 07 & VT.r & ثُوَرجه \\
\hline 11.7 & 15.9 & $1 \mathrm{rA \Lambda} \cdot 0.7$ & 107 & GTYq & 119.5 & هاموون \\
\hline 17.0 & ro.1 & rovo.V.V & rAT & 7011 & $107 . \varepsilon$ & سار بهستى \\
\hline$\varepsilon \Lambda, r$ & $\leqslant \varepsilon .9$ & $\varepsilon \leqslant 9 \wedge \vee \leqslant .7$ & IVT & $7 \wedge v$ & 9 qт. & هلرموّته \\
\hline$r \wedge . \wedge$ & rA. $r$ & rArl.9. & rیq & OVYr & VY.V & كهكون \\
\hline 1r. & V.r & VrorI.r & $r \leqslant r$ & $\varepsilon \vee q$. & $0 \leq .1$ & باواجى \\
\hline 17.0 & $0 . r$ & or.V१. \& & $1 \cdot v$ & & T1.7 & كيّله خوار \\
\hline ---- & ---- & ---- & ---- & $0 \leq r T$ & $1 \leq \cdot .9$ & زانكوّ \\
\hline ---- & ---- & ---- & ---- & TVY & 117.8 & كاشتنيارى \\
\hline ---- & ---- & ---- & ---- & ---- & $r \cdot .9$ & للمنطقة الصناعية \\
\hline---- & ---- & ---- & ---- & ors & VT.r & كـميىى زانكو \\
\hline
\end{tabular}

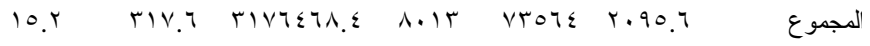

المصدر: من عمل الباحث استخدام (GIS) اعتمادا على مديرية بلدية كويه القسم الفني، وعلى

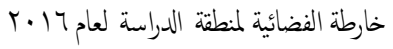

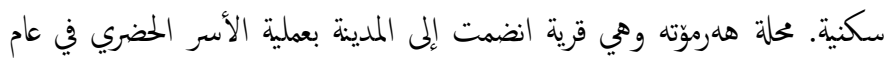

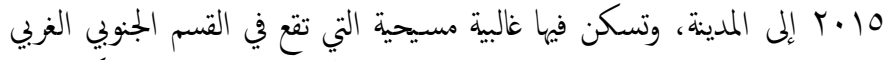

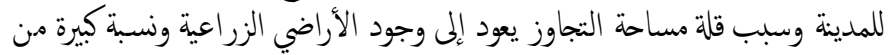

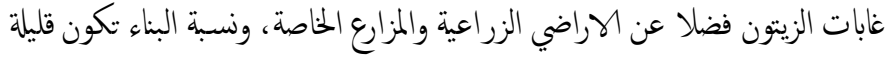

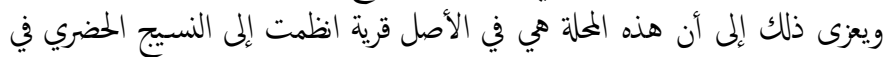
الآونة الاخيزة.

Y. بحلة ثازادى

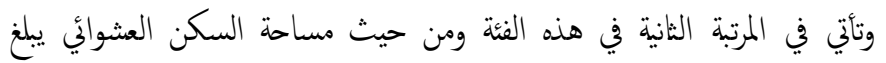

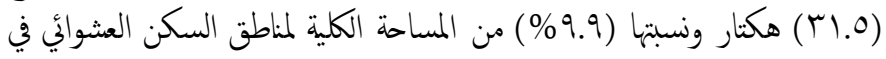

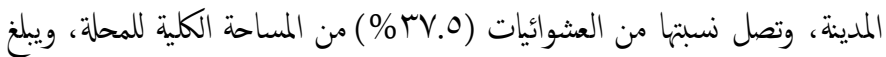

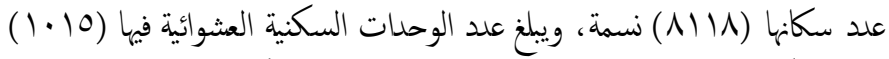

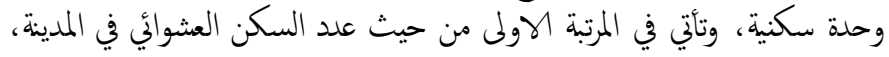

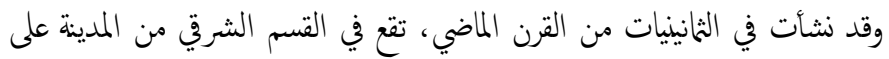
طريق كويه-رانيه. r. - محلة كلكون

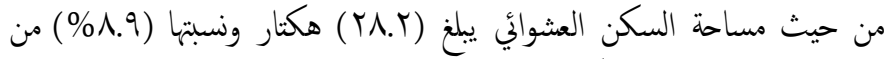

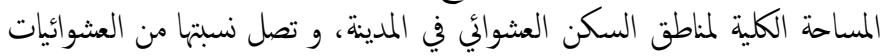

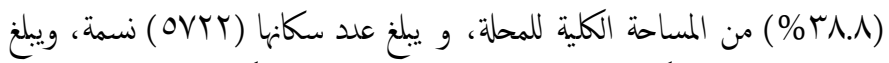

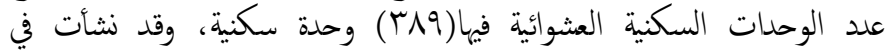

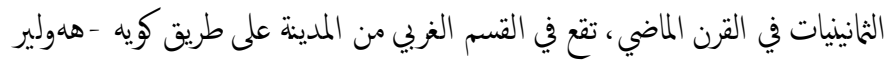

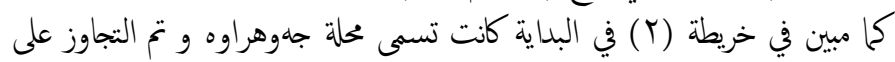

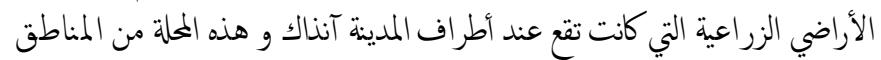

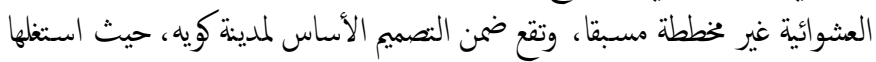

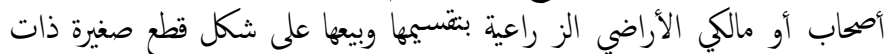

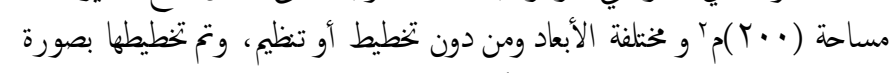

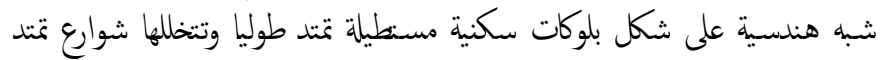

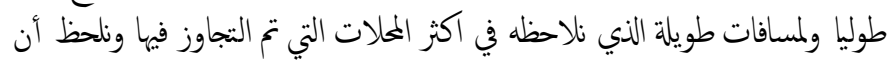

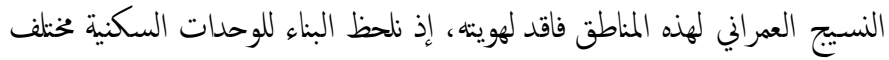

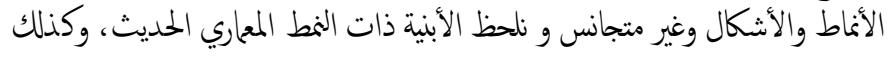

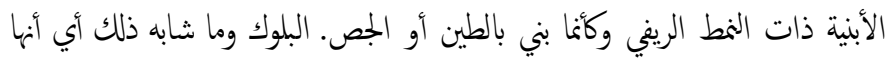

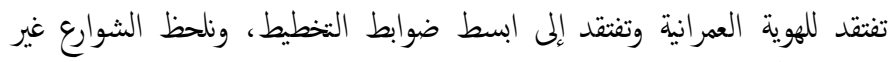
منظمة الأبعاد وليس فيها تدرج هرمي ووظيفي وغير معبدة. ع. محلة بدفرى قهندى

و تأتي في المرتبة الرابعة محلة بهفرى قهنلى، حيث مساحة السكن العشوائي يبلغ

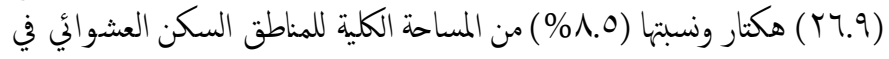

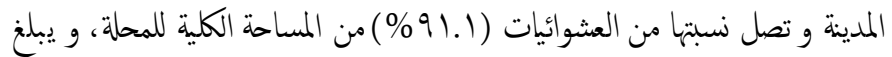

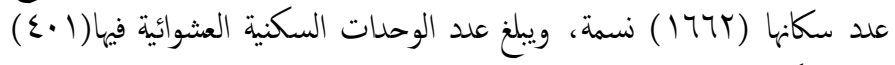

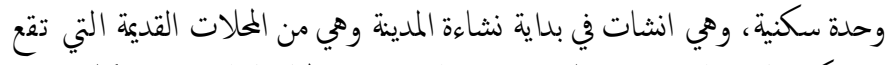

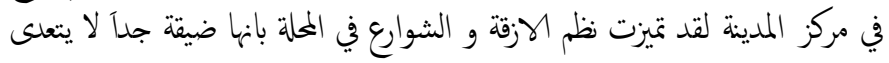

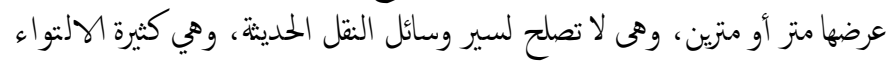

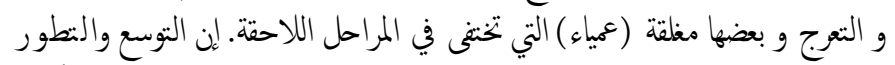

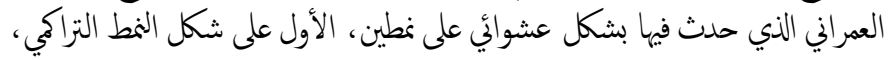


استعجالات سكنية لغرض تأمين أراضٍ سكنية وربط نمو المدينة واتساعها بنمو السكان

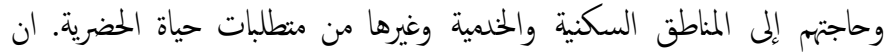

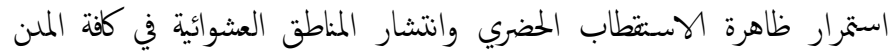

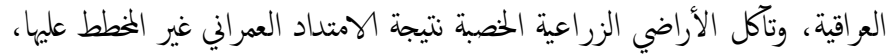
وبالتالي تدهور البيئة العمرانية فيها. الفئة الثاية

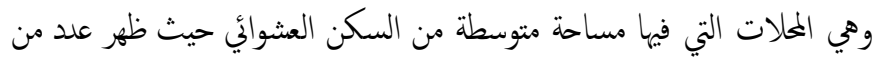

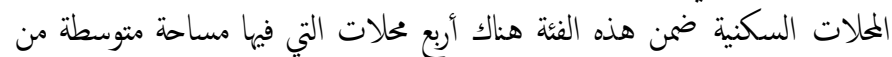

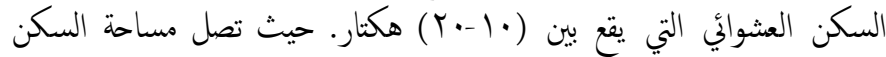

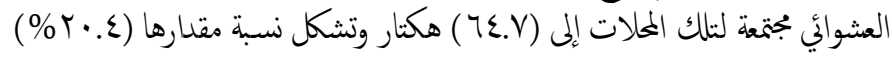

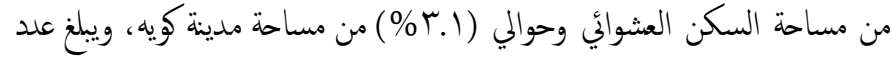

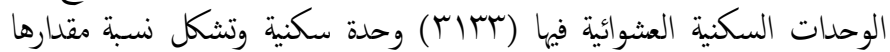

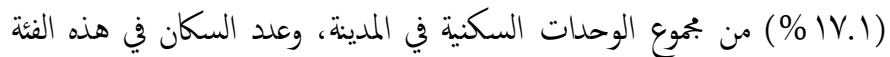

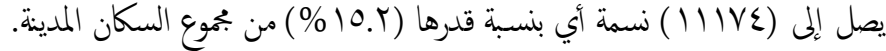

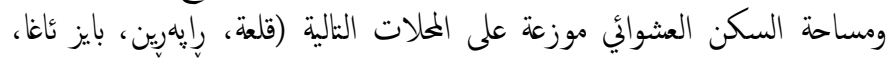

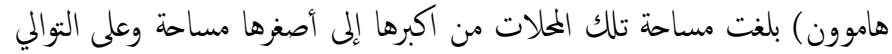

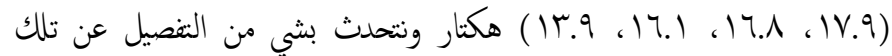

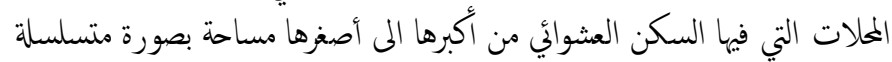
وعلى النحو الاتي:

ا محلة قلعة

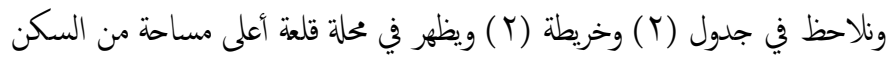

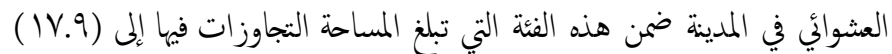

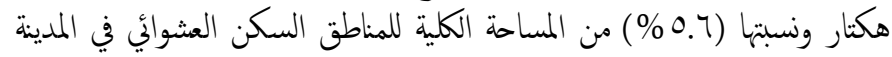

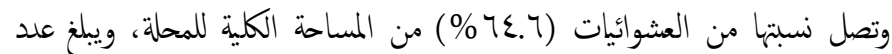

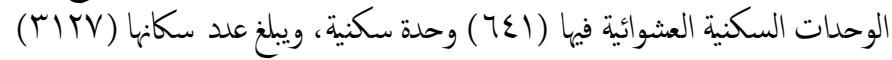

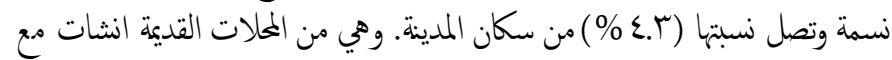

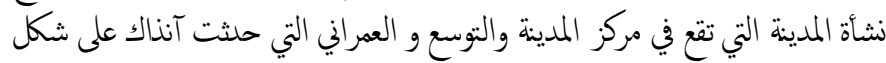

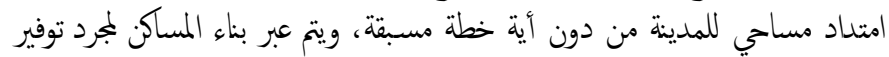

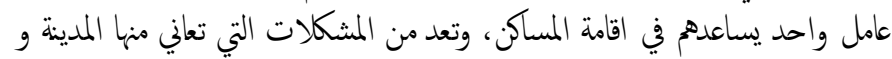

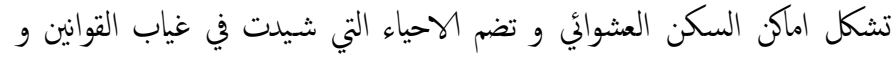

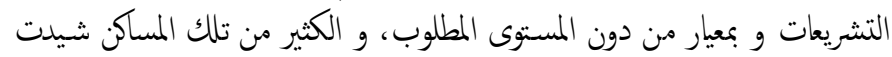

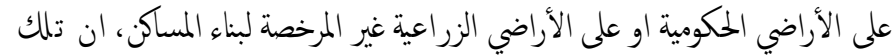

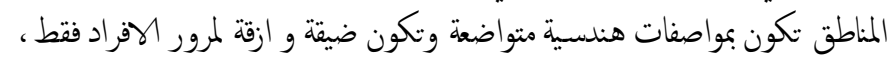

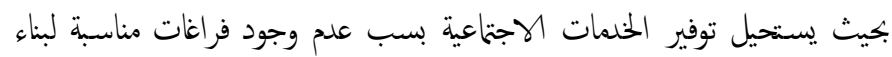

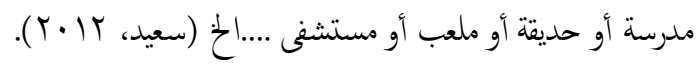

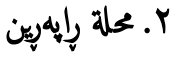

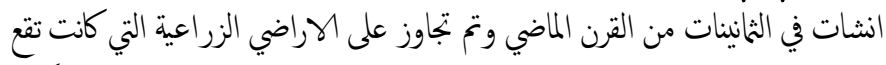

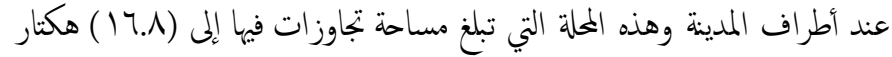

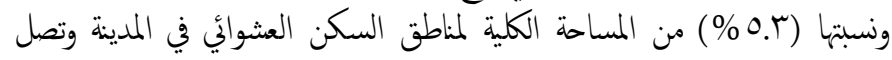

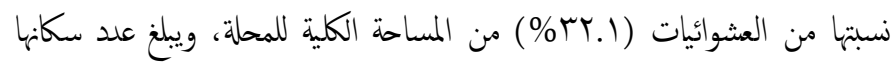

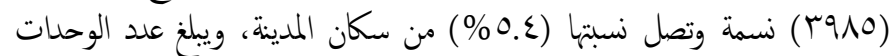

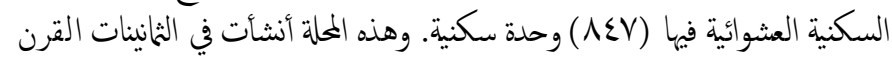

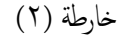

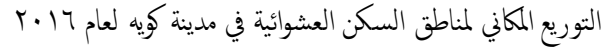

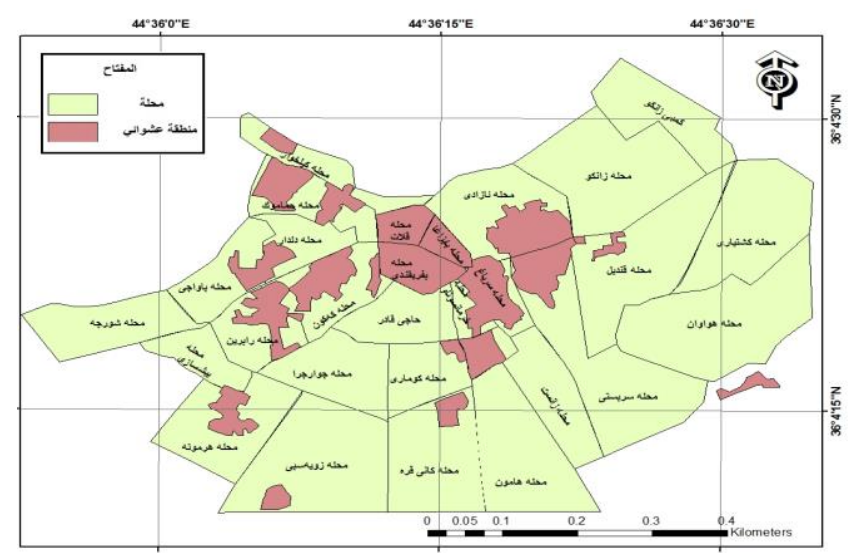

المصدر: استخدام (gis) باعتماد على الصورة الفضائية لمدينة ويه واعتمادا على ألجدول (T)

7 . محلة حهماموّك

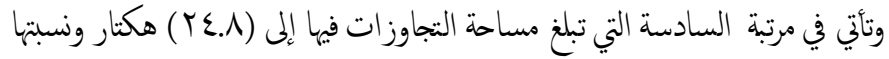

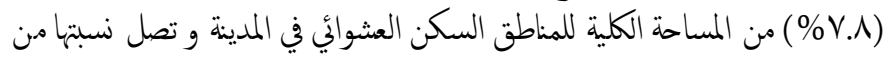

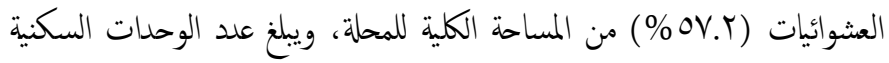

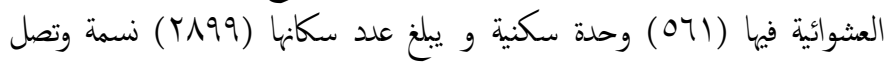

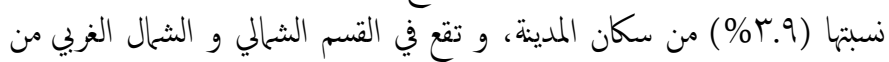

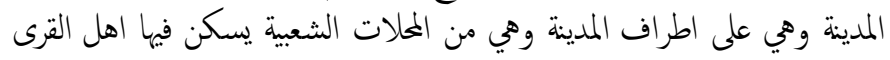

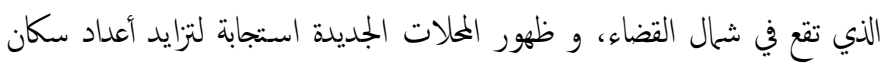

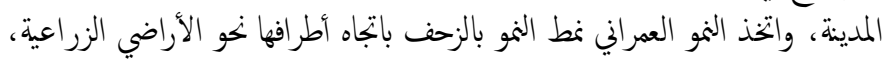

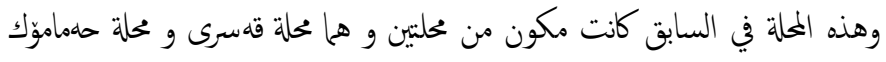

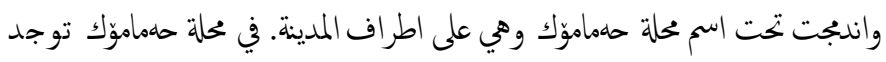

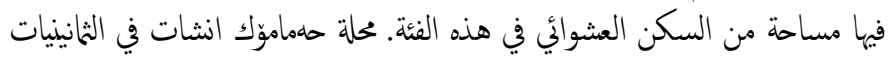

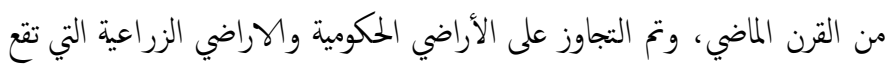

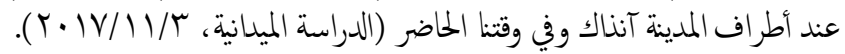

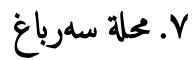

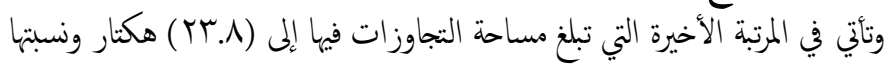

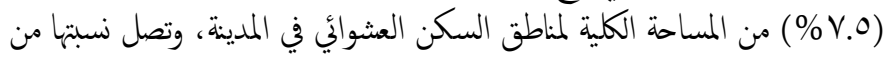

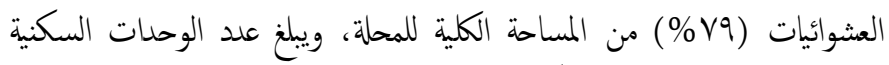

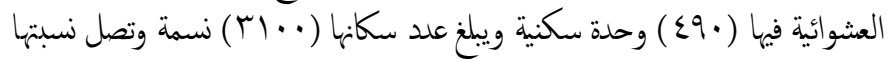

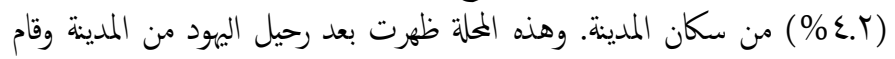

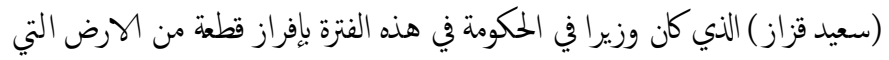

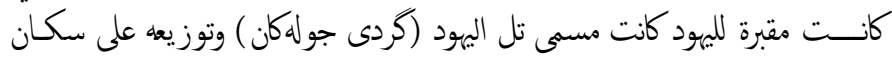

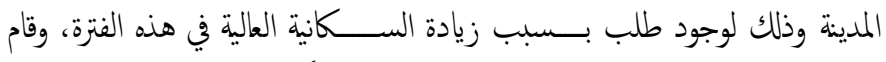

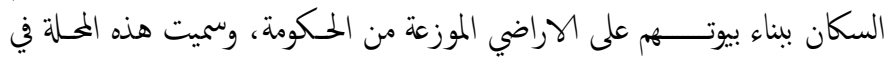

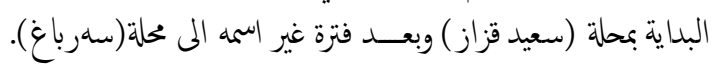

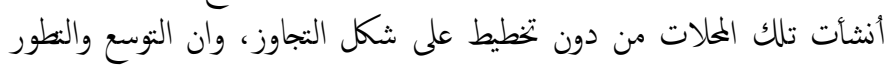

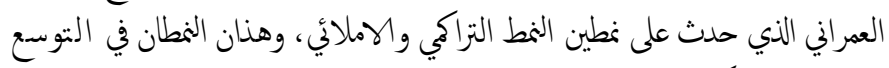

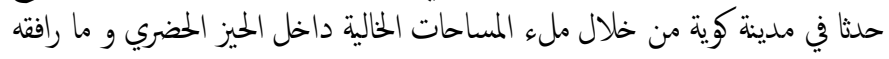

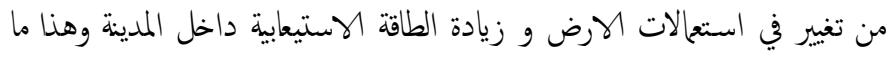

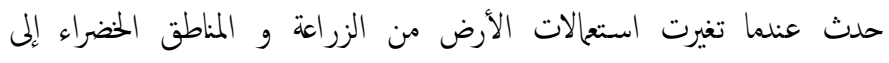




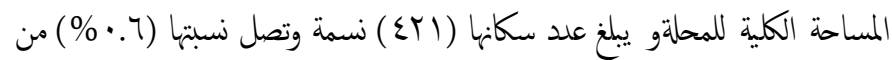

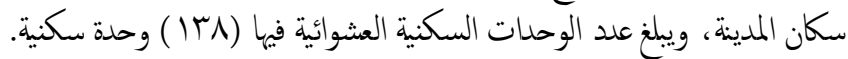
ب. محلة دلّار

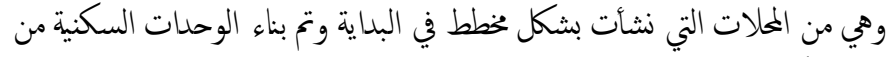

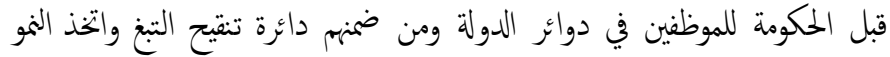

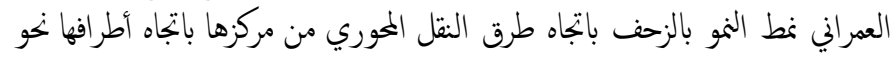

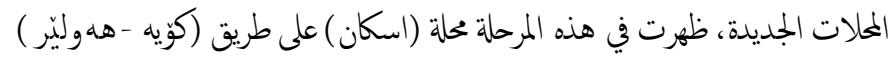

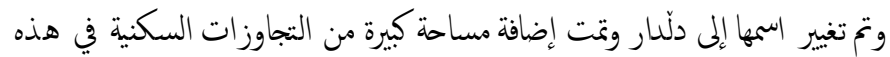
المحلة، ويبلغ عدد الوحلات السكنية العشوائية فيها (Y ب ب ) وحدة سكنية.

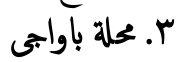

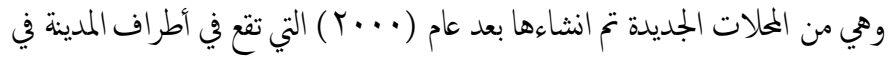

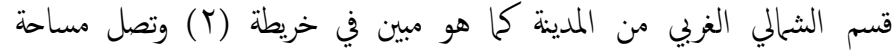

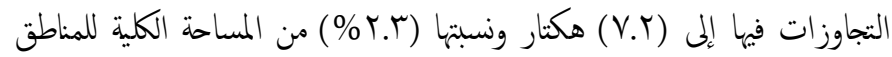

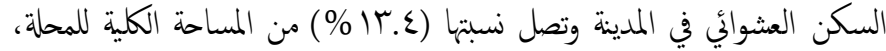

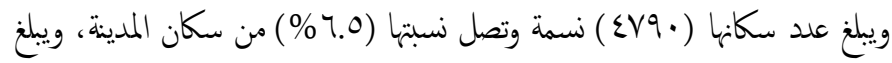
علد الوحات السكنية العشوائية فيها (بع (ب) وحدة سكنية.

ع. محلة زمويه سيى

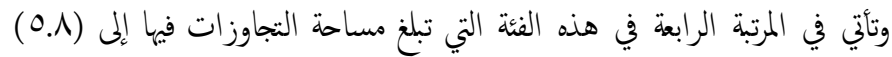

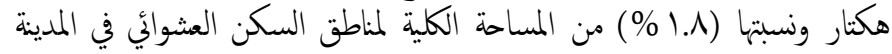

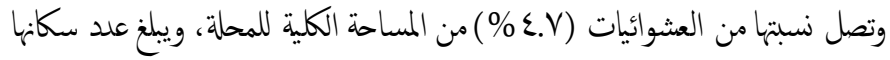

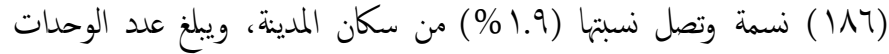

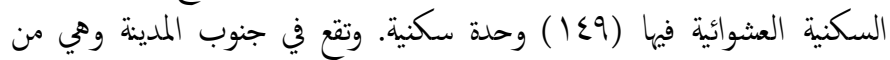

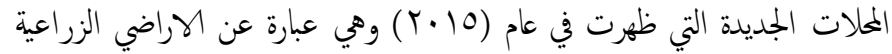

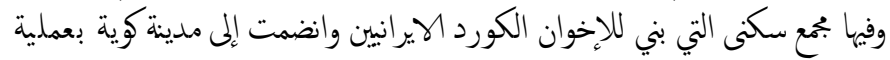

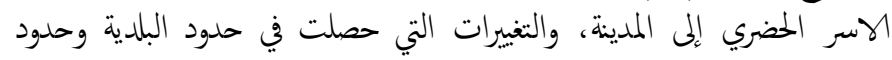

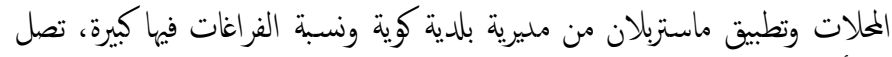

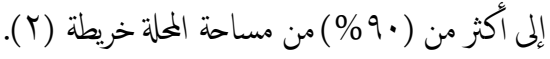
0

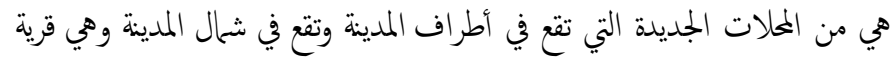

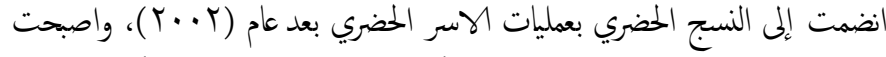

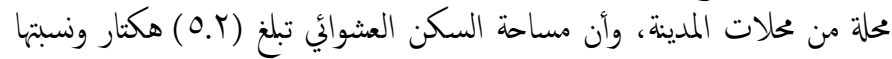

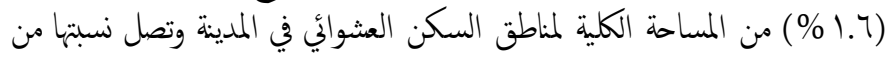

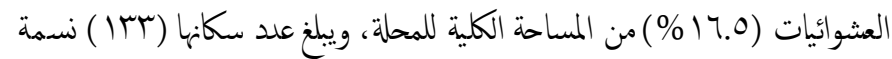

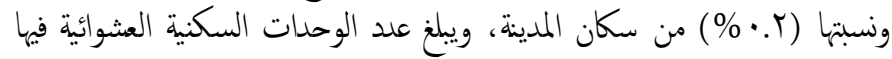
(1·V)

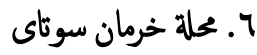
وهي من المحلات القريبة من مركز المدينة وتقع في جنوب المدينة كما مبين في خريطة

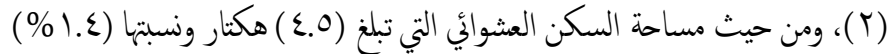

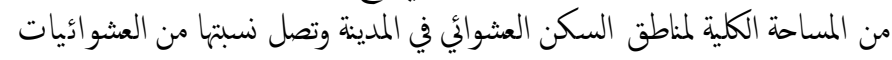

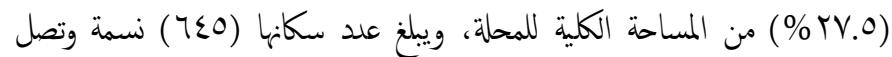

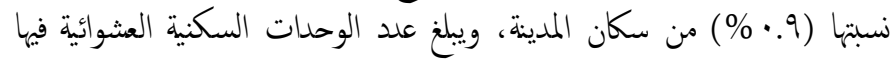

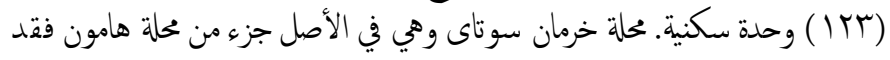

الماضي، في البلاية هذه المحلة مسمى محلة عهليماو6 وان مساحة الوحلات السكنية (YO-Y...)

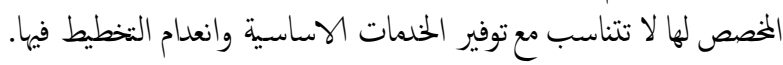
r. r. محلة بايز ائاغا

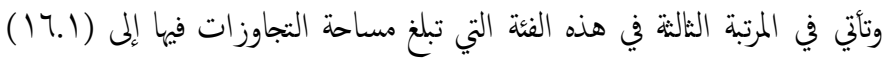

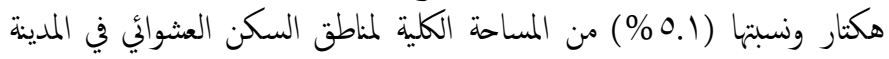

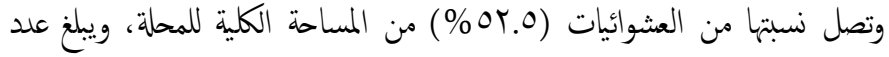

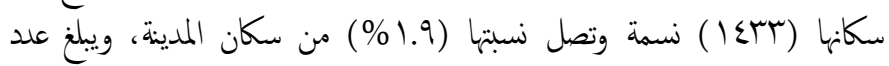

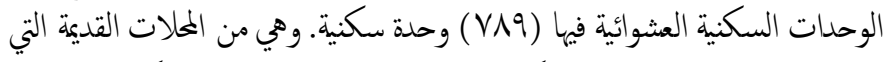

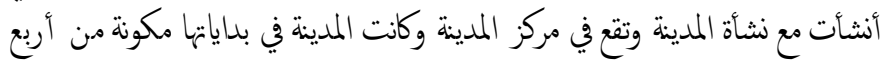

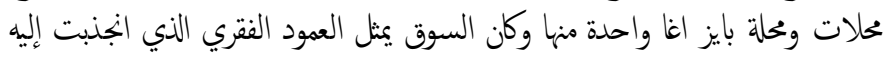

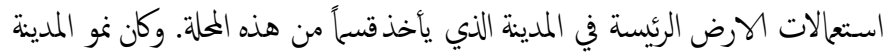

ع. محلة هامون و هذه المحلة أنثأت في الثانينات وكانت في البلاية تكونت من محلة(شهوكيراوه) وهي

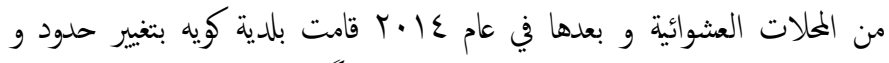

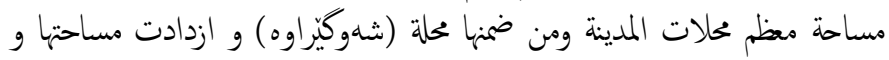

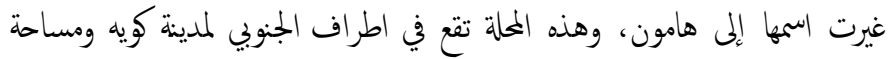

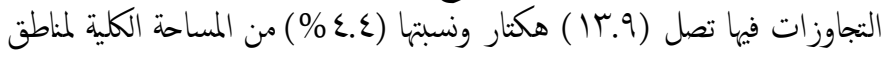

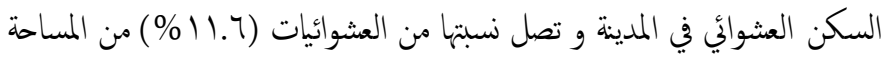

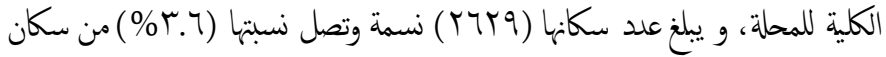

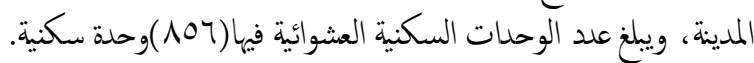

الفئة الثالثة

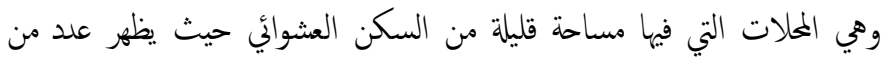

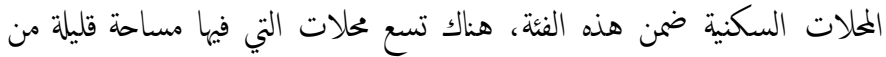

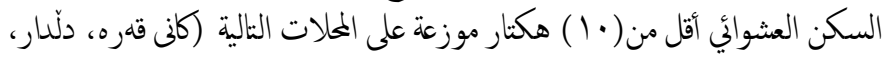

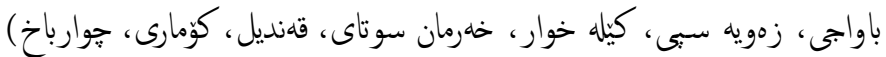

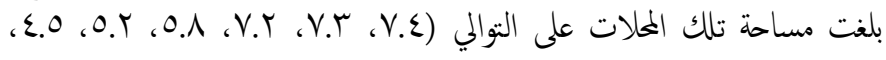

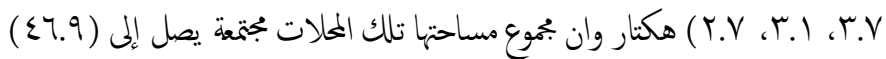

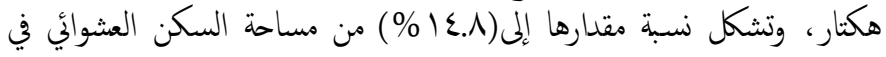

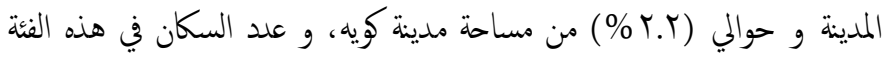

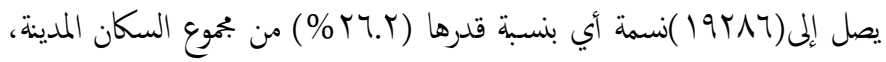

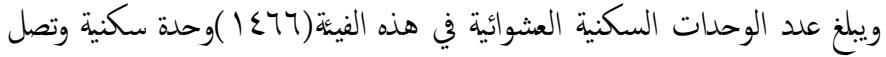

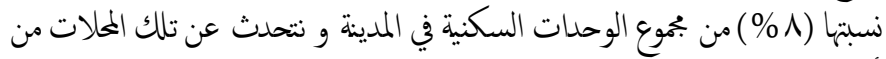
أكبرها إلى أصغرها مساحة بصورة متسلسلة وعلى النحو الاتي:

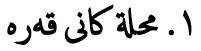

وهي من المحلات الجديدة انضمت إلى مدينة كوية بحسب التغيرات التي حصلت في

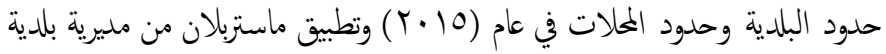

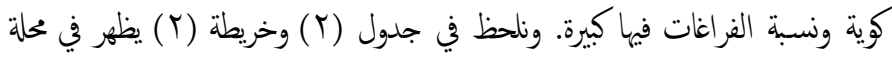

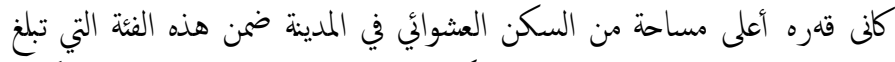

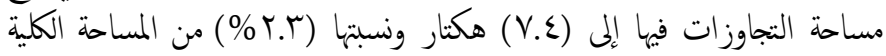

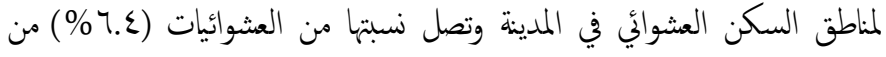


(زانكو ، كمبيى زانكو ، المططقة الصناعية، حاجي قادر ، هواوان، جوارجرا، زانست،

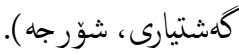

\section{ع ـ المسوغات التي ادت إلى ظهور السكن العشوائي في مدينة كويه}

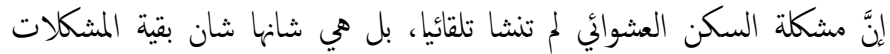

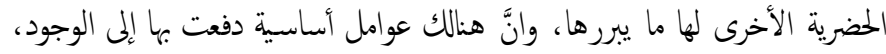

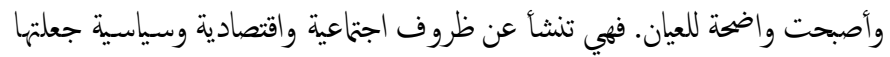

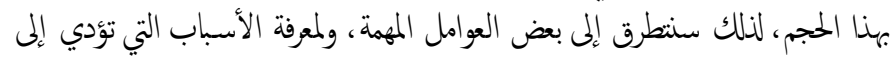

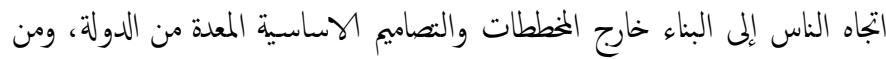

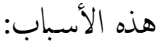

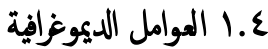

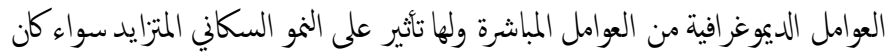

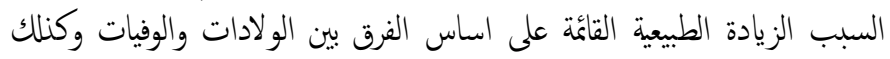

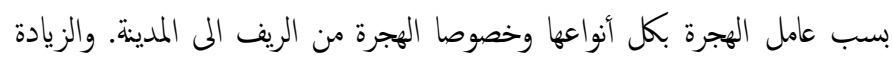
الطبيعية للسكان وانشطار العوائل الكبيرة.

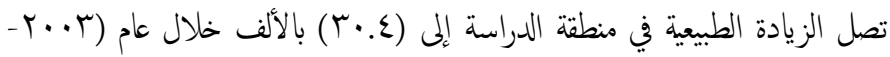

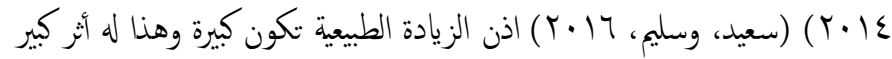

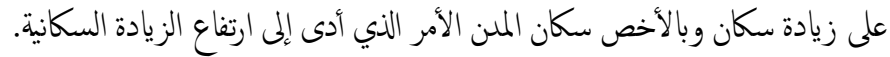

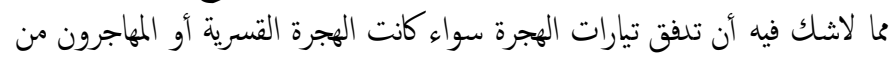

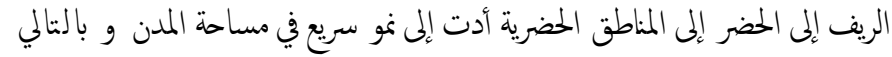

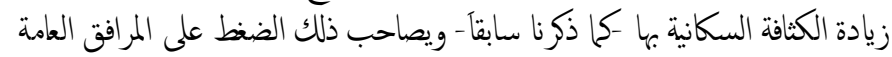

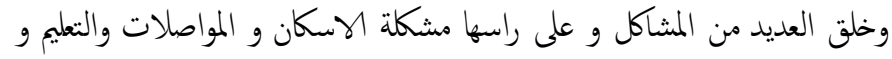

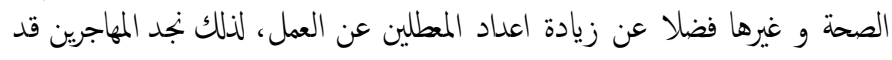

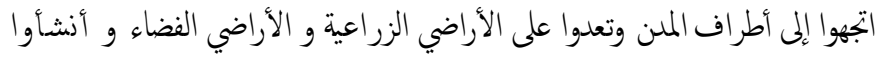

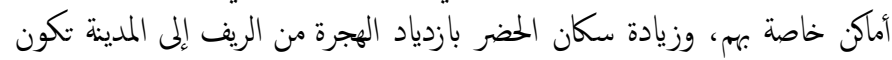
ذات تأثير أكبر على زيادة حجم السكان للمدينة.

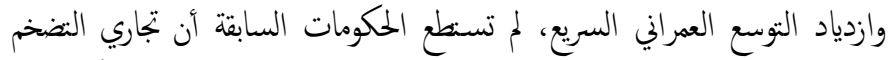

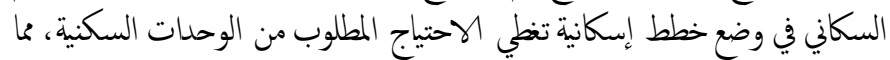

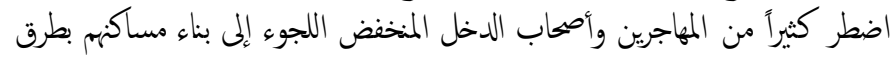

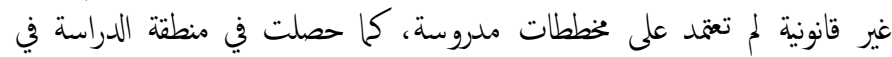

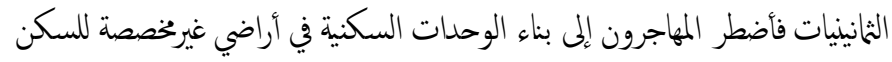

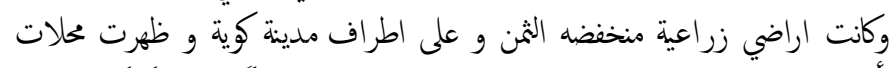

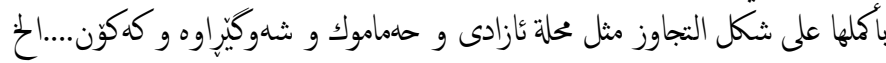

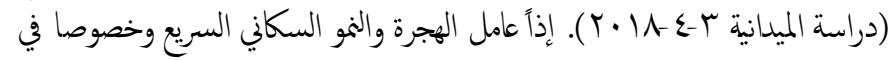

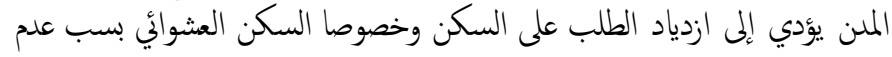

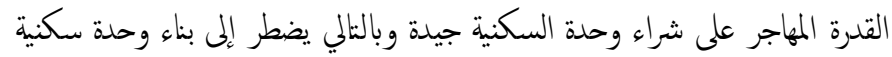

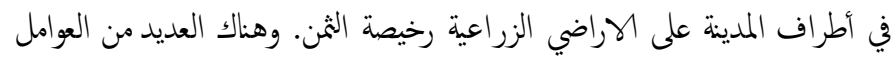

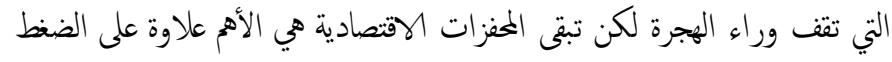

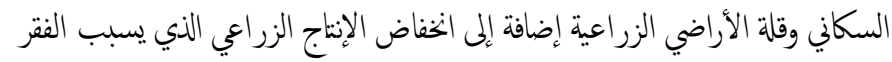

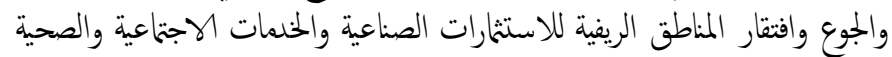

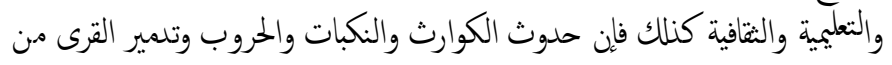

تم استقطاعها في عام 10 ـ ب وهي اصلاً أراضي زراعية تم بيعها بشكل قطع أراضي

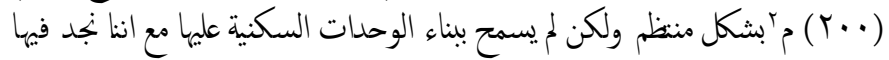

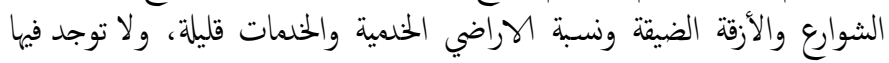

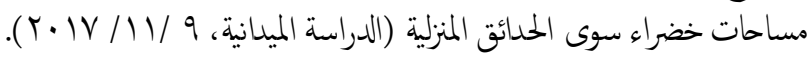

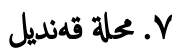

وتأتي في المرتبة السابعة في هذه الفئة التي تبلغ مساحة التجاوزات فيها إلى (r.V)

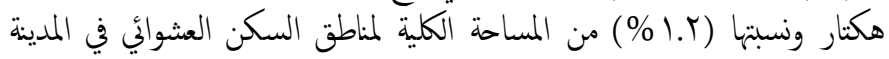

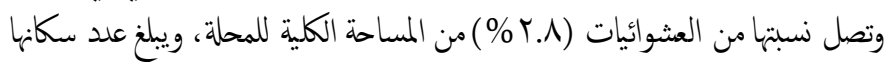

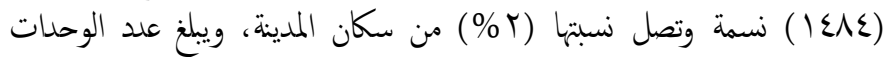

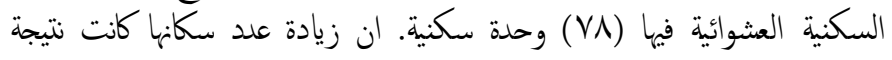

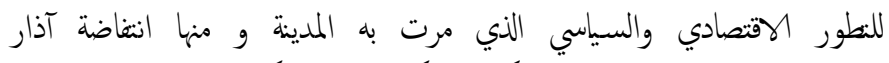

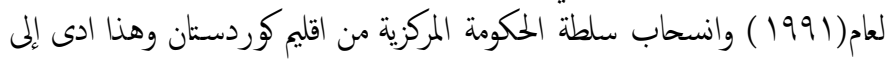

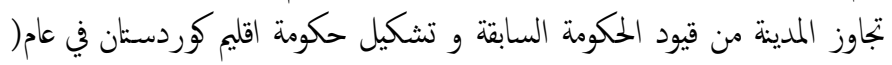

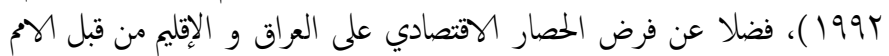

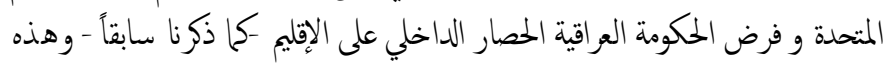

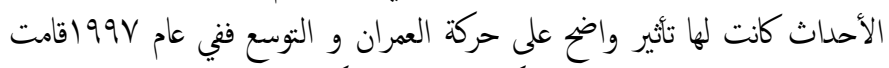

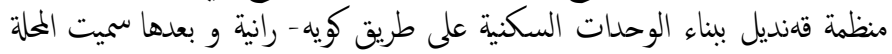

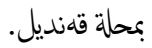

1. 1. محلة كومارى

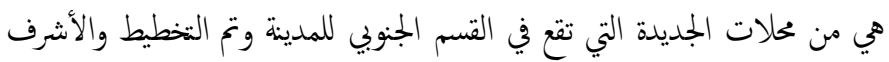

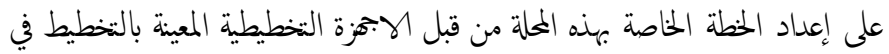

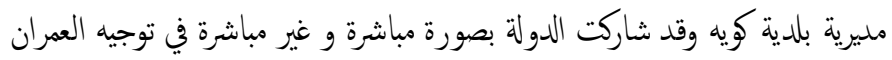

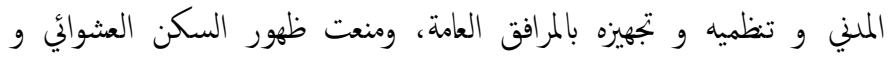

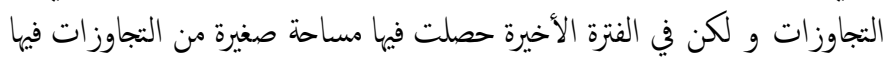

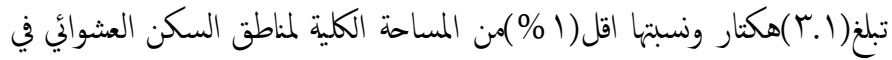

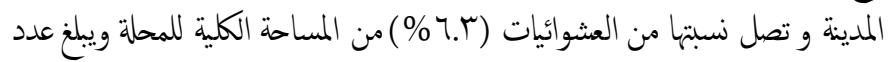

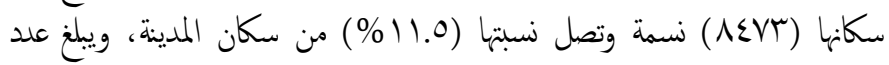

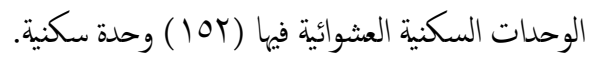

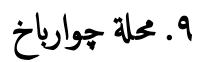

وتأتي في المرتبة الأخيرة في هذه الفئة التي تبلغ مساحة التجاوزات فيها إلى (Y.V)

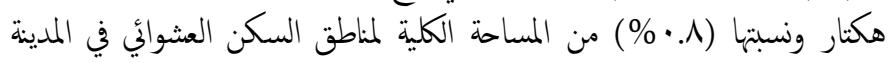

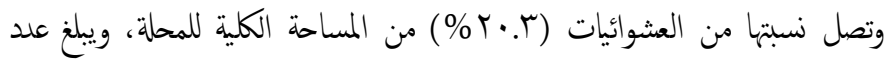

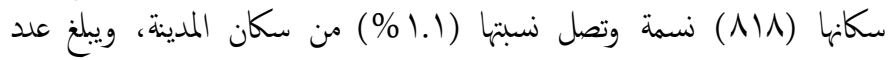

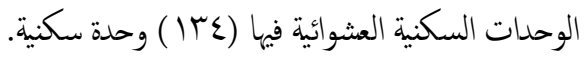

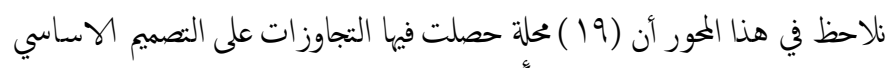

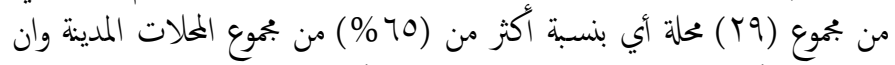

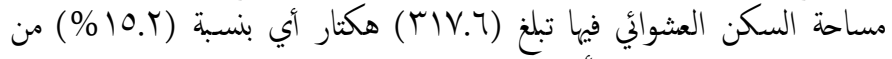

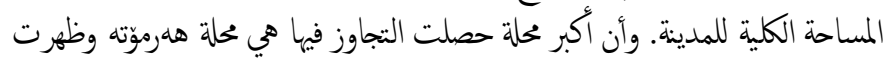

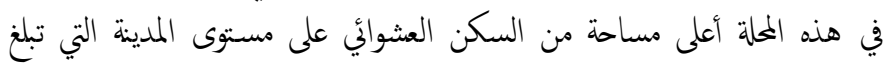

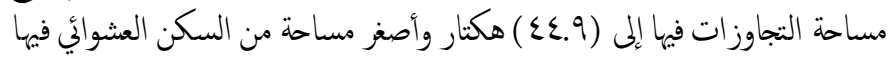

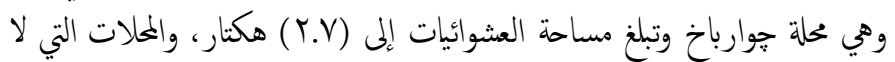

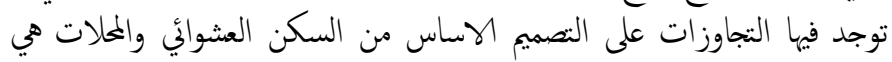




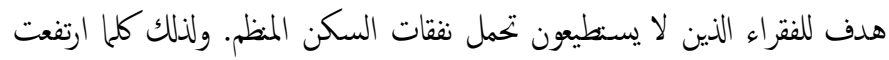

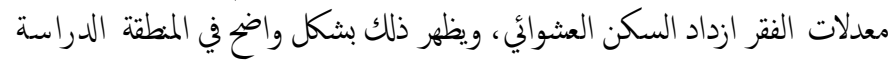

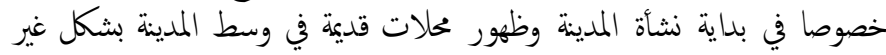

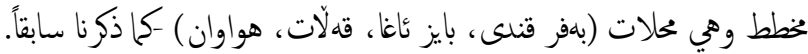

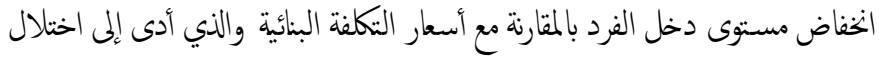

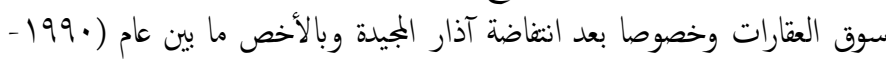

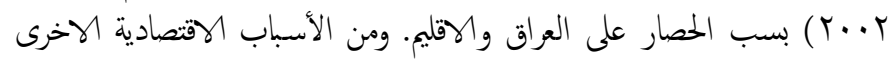

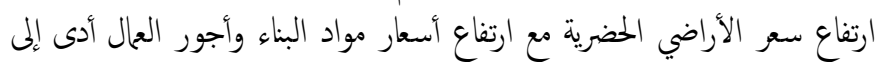

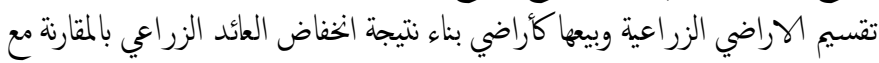

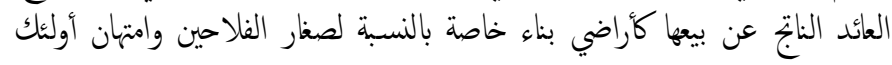

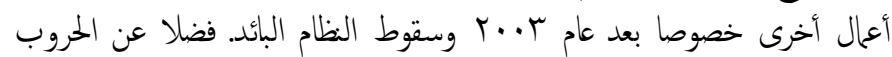

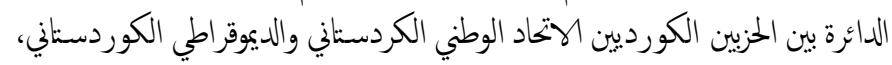

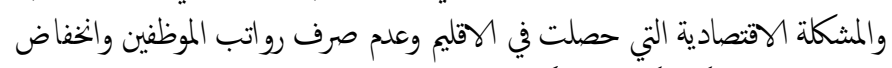

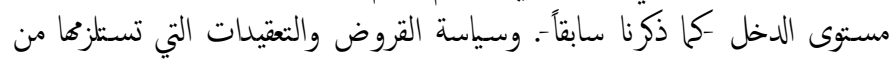

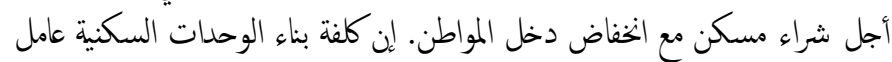

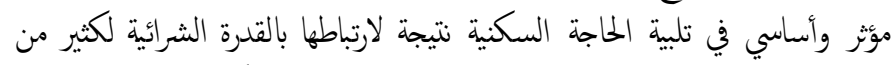

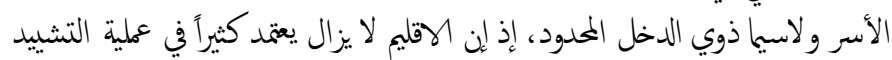

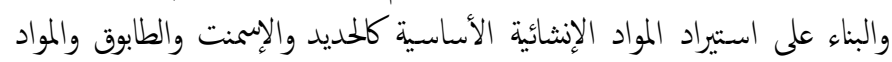

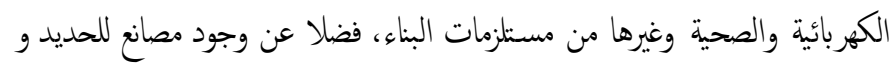

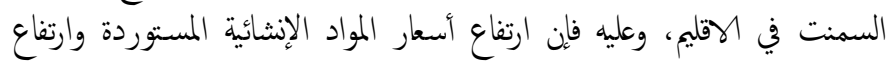

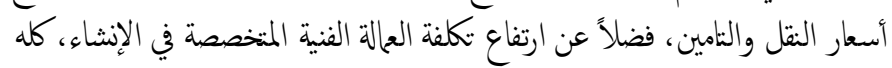

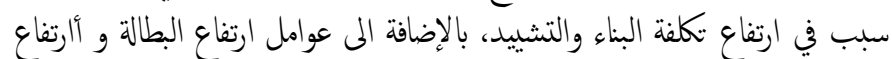

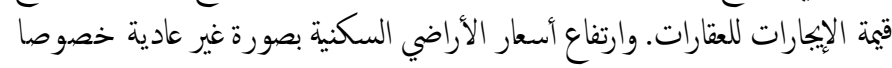

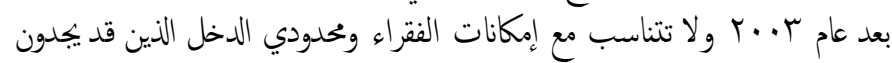

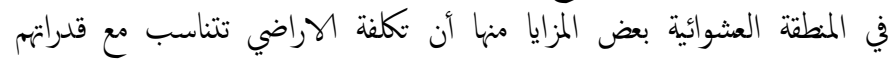

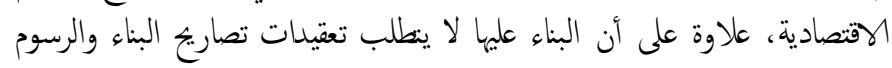
الباهظة التي تلفع دخول سوق الاسكان الرسمي سواء بصفة رسمية أو غير رسمية.

\section{ع ع الموامل السياسية والتشربية}

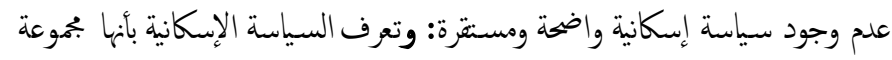

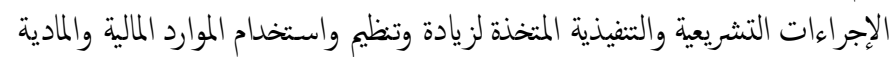

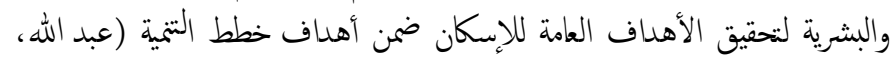

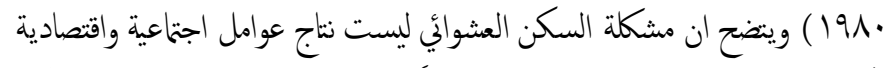

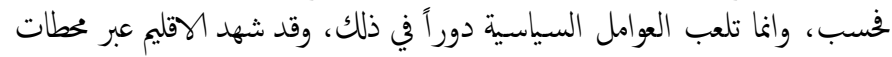

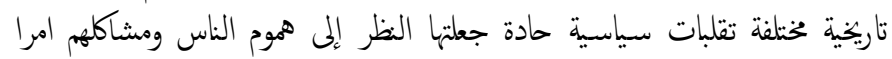

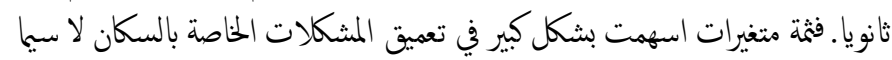

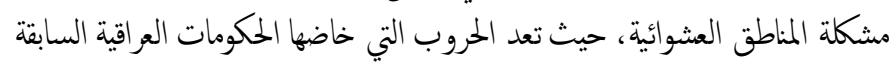

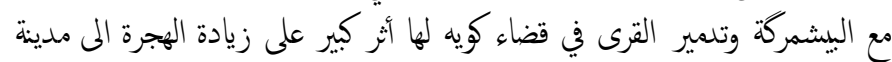

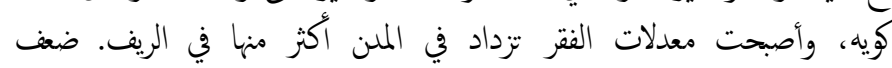

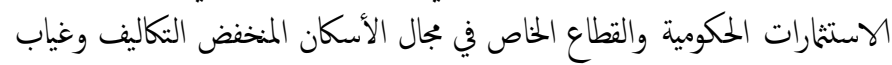

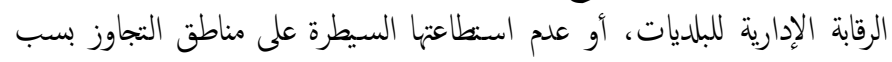

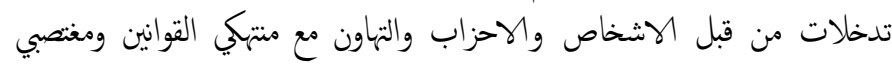

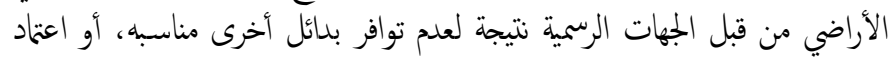

قبل الحكومة العراقية وتعاقب فترات الجفاف بسب التغيرات المناخية كلها تمثل عوامل

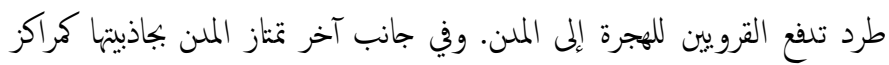

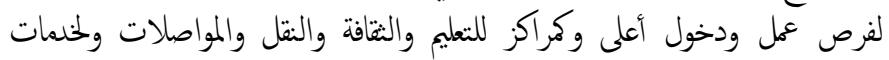

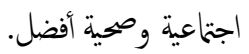

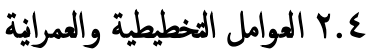

السبب الرئس هو ضفف القانون أو غيابه خصوصا في بلاية تشكل الدولة العراقية

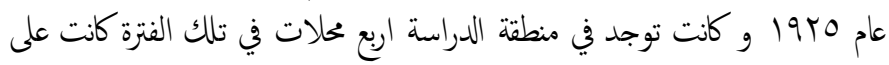

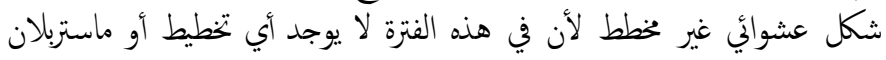
(Master Plan) وتوفير مأوى في أغلب المدن العراقية و تطبيق تصاميم الاساس للمدن المان و و في منطقة

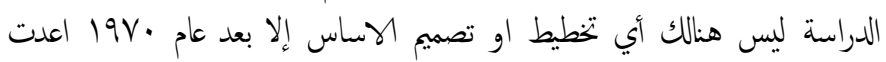

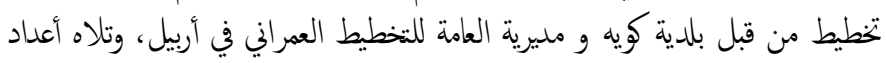

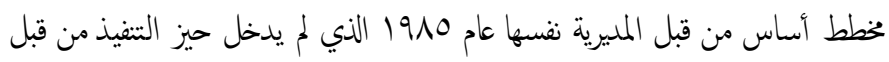

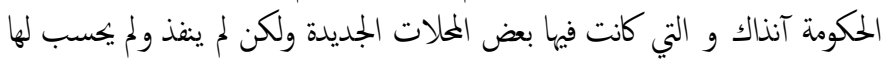

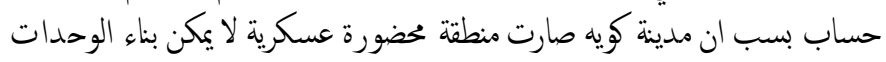

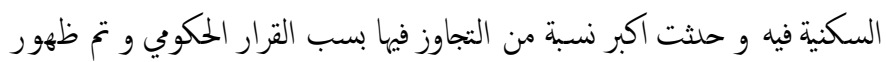

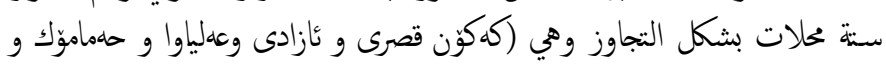

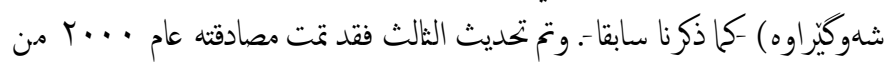

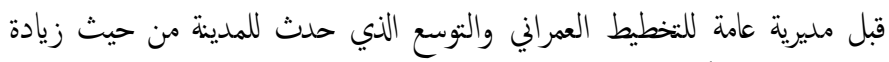

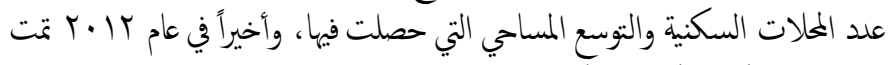

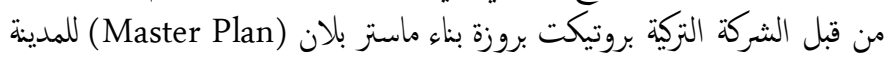

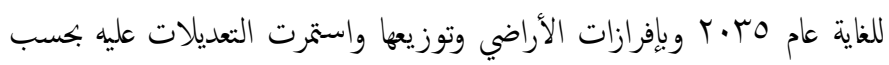

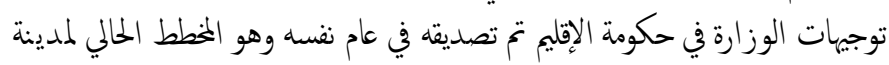

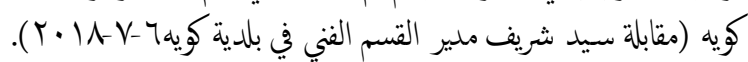

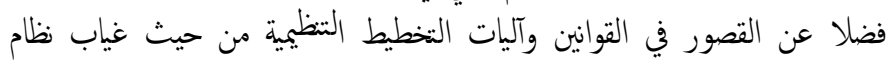

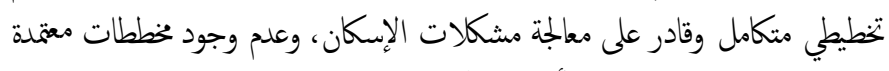

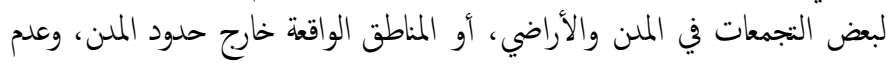

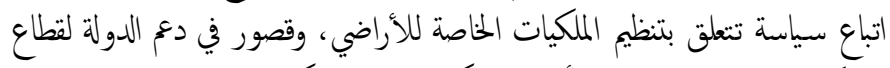

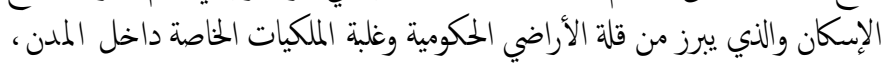

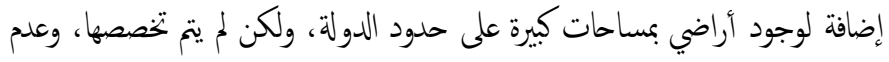

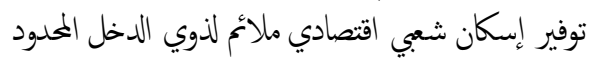

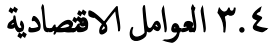

للعامل الاقتصادي أثر كير في نمو المدن وزيادة جممها؛ لأن تطور الصناعة والقطاعات

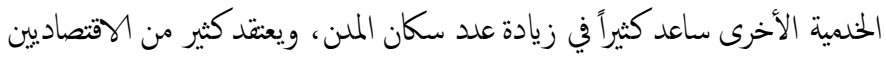

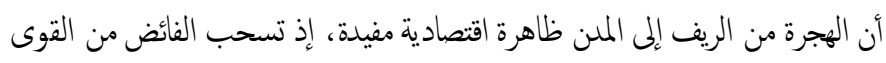

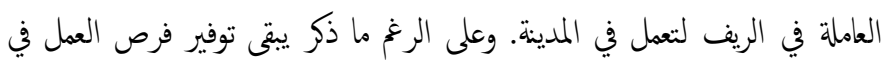

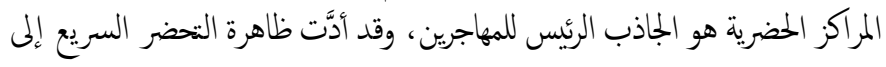

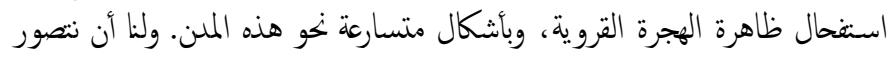

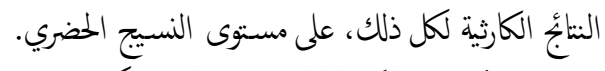

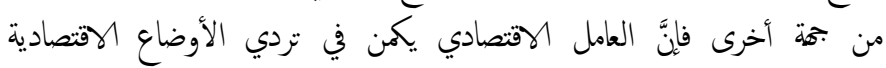

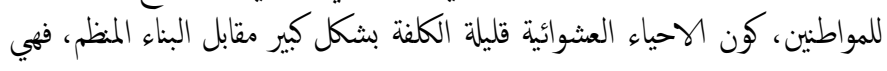


حين بلغت المساكن العشوائية الثابعة لمحلة هلهموته الى (IVT) و (IVT) وحدة سكنية عشوائية

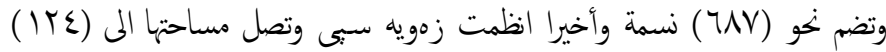

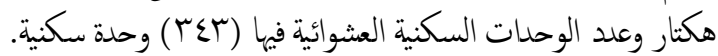

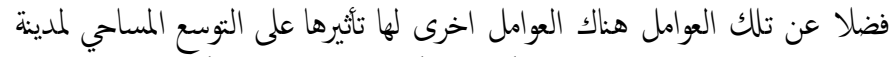

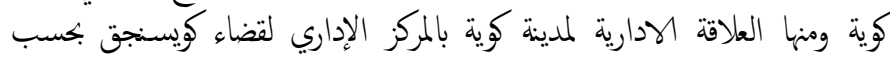

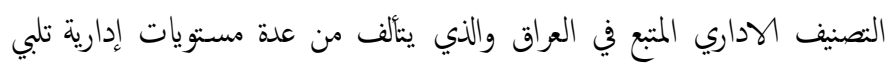
حاجات السكان في عوم القطر هي العاصمة والمحافظة وقضاء.

\section{1.استنثاجات}

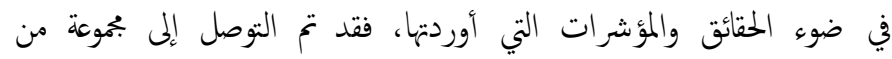

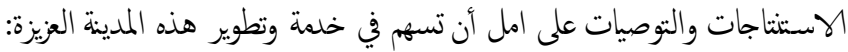

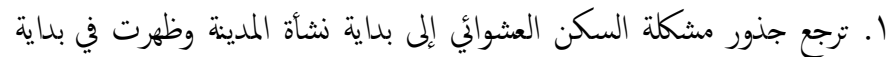

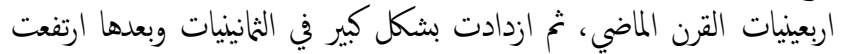

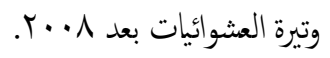

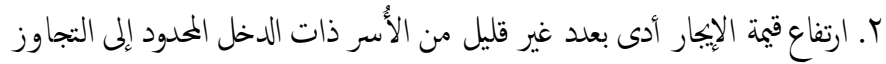

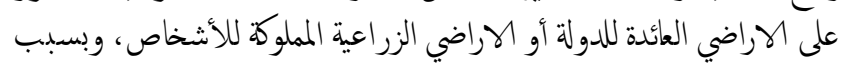

ضفف رقابة البلدية.

r. لمشكلة العشوائيات أبعاد عديدة منها سكانية بسبب تزايد السكان المفرط نتيجة للاججرة الداخلية، وبسبب تلنى مستوى الدخل وهنا عامل المباد اقتصادي مقارنة

ع. انماط السكن العشوائي تنقسم على بمحوعتين، المجموعة الاولى هي (المحلات

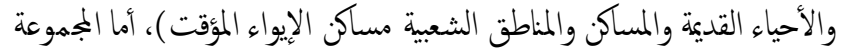

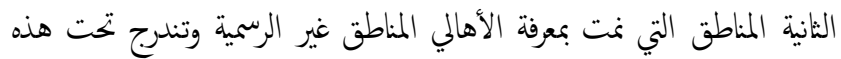

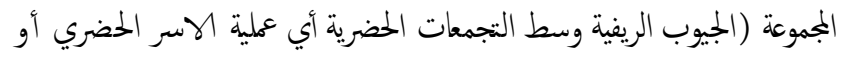

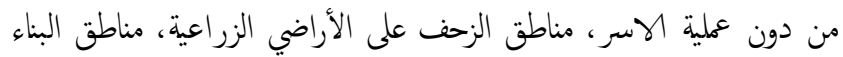

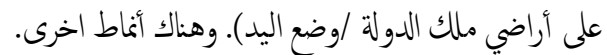

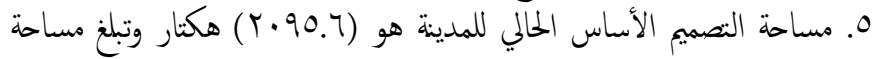

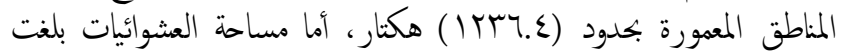

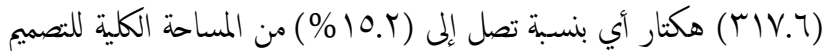

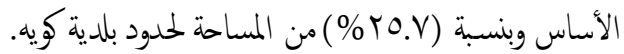

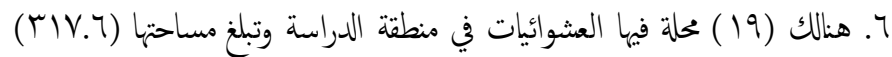

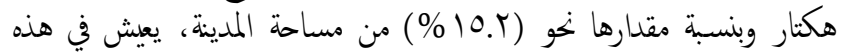

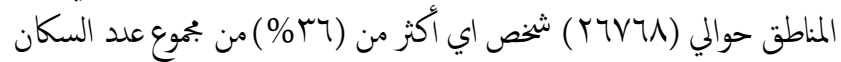

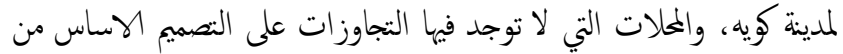

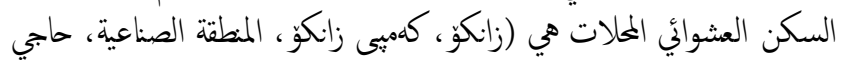

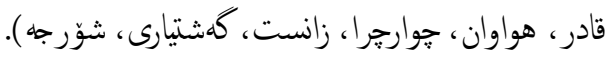

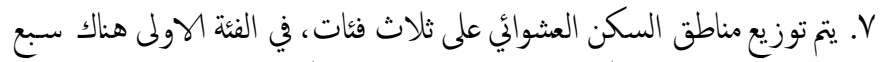

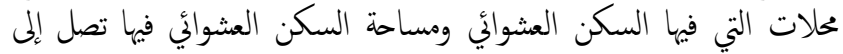

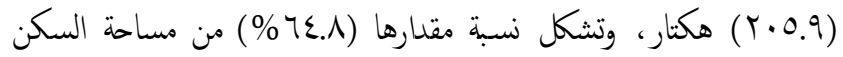

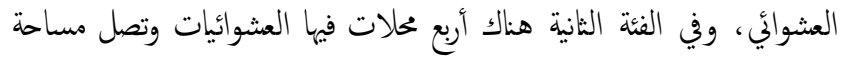

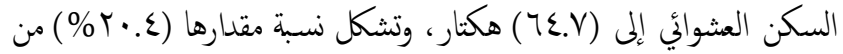

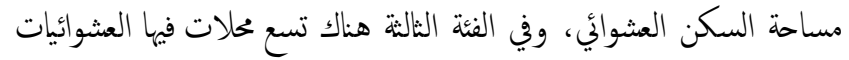

السياسيين على أصوات سكان الأحياء العشوائية إلى العقلة المستمرة لإزالة هذه الماته

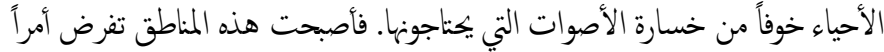

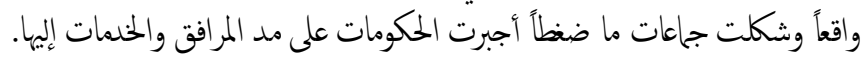

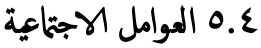

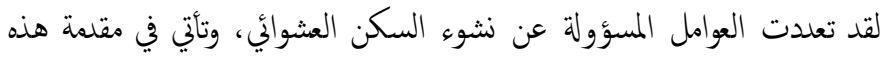

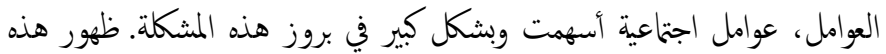

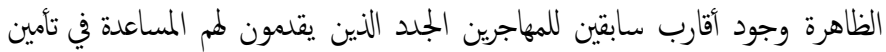

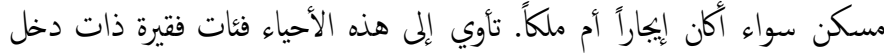

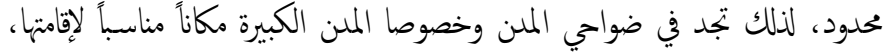

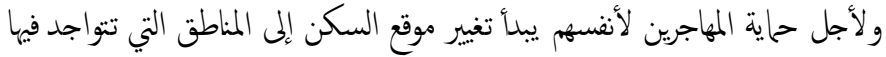

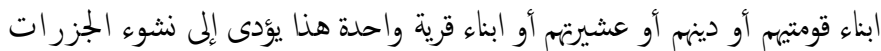

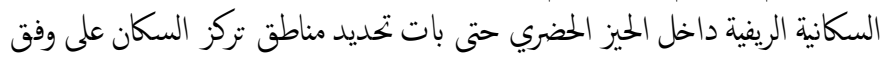

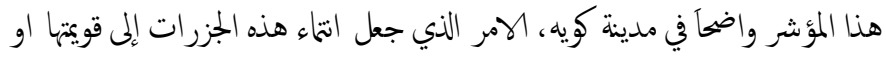
دينها او قبيلتها و بنلك فقد السكان الوافدون إلى المدينة خاصية الانتماء لها، وهنا

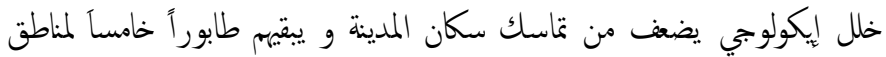

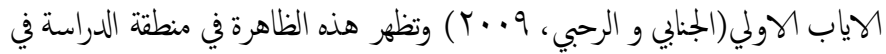

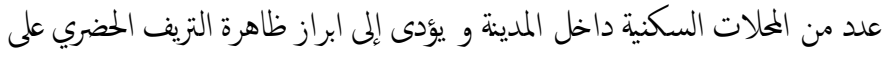

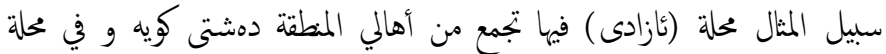

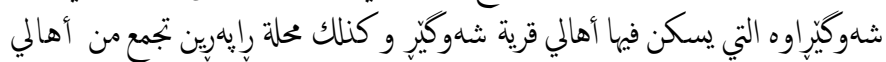
طق طق و الطرق المؤدية المى طق طق و محلة حهمامؤك......الخ.

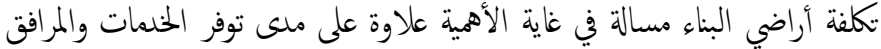
والقرب من مناطق العمل.

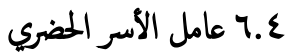

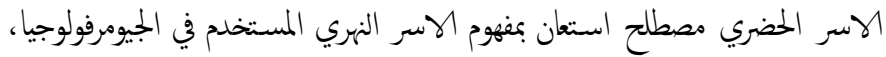

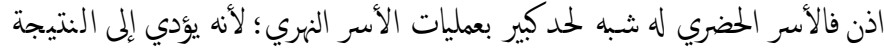

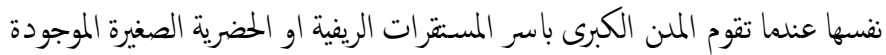

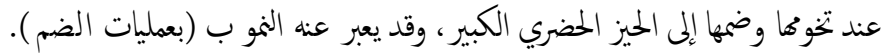

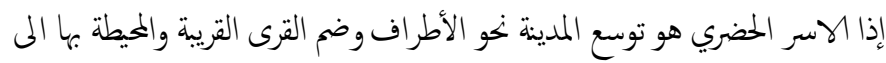

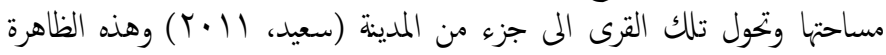

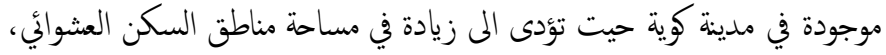

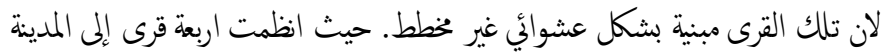

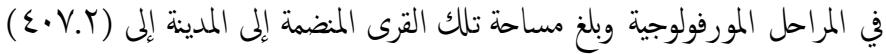

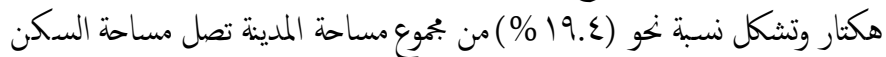

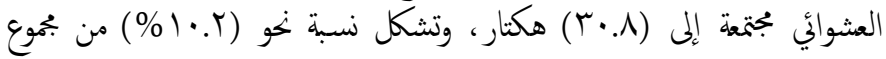

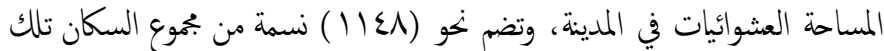

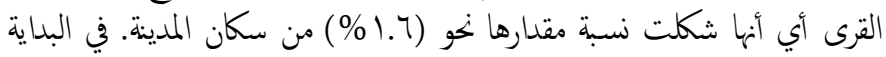

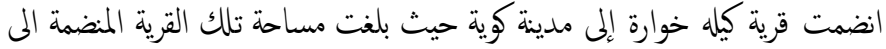

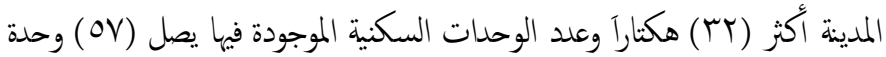

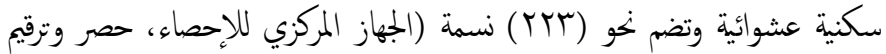
المباني (Y.? (Y.9)

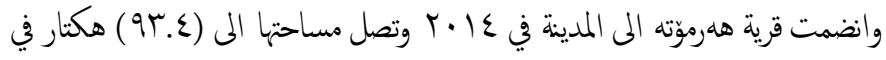


تشرين للبحوث والدراسات العلمية سلسلة العلوم الهندسية (المجلد سه)، العدد سا.ب، ب، ص ص

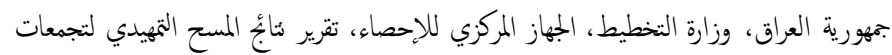

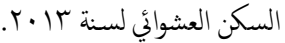

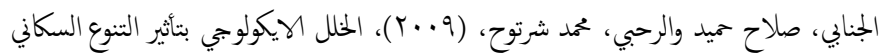

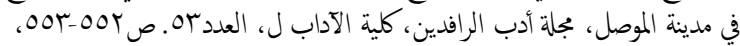

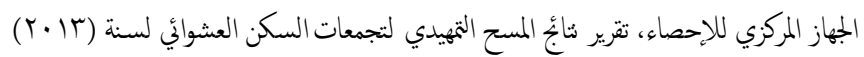
الجهاز المركزي للإحصاء، حصر وترقيم المباني (9. (†).

رشوان، حسين عبد المميد، (199V)، مشكلات المدينة دراسة في علم الاجتاع الحضري المكنب

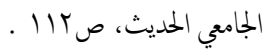

ززكنة، حسن محمد حسن، (ب/ (Y)، العشوائيات السكنية دراسة في جغرافية المدن، دار

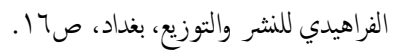

سعيد، كامران طاهر ، (Y (Y)، توسع مدينة السليمانية بتأثير الاسر الحضري دراسة في جغرافية

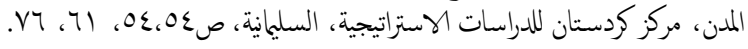

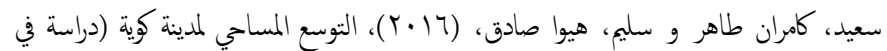

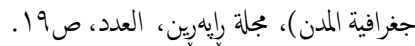

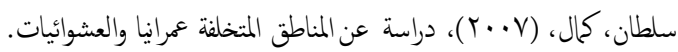

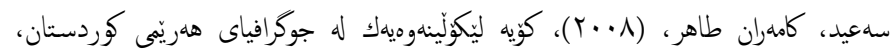

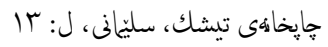

الشيباني، عمر محد التومي، (1990)، الأسس النفسية والتربوية لرعاية الشباب، دار الثقافة،

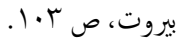

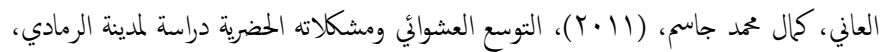

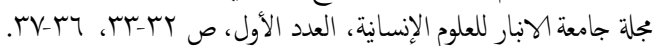

عبد الله، نجلاء، (•191)، مشكلة السكن في العراق واقعها وسبل معالجها"، رسالة ماجستير

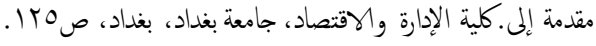

عوض، السيد حنفي، (199V)، سكان المدينة بين الزمان والمكلان، المكتب العلمي، الإسكندية، ص 190

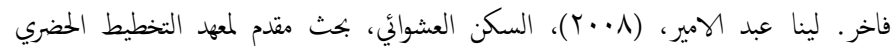

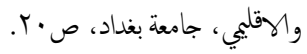

كوة، حيدر، (ب/191)، دور ججاز الشرطة البلدية في منع التجاوز على التصاميم الأساسية،

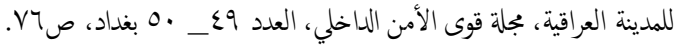

مصطفى، علا واخرون، (1991)، الطفل في المناطق العشوائية، المركز القوي للبحوث الاجتماعية

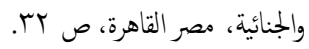

منظمة الام المتحدة، (1990)، المستوطنات العشوائية في العالم الثالث، اللجنة الاقتصادية

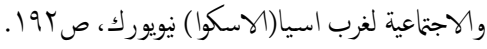

Y. IV/

دراسة الميدانية بتاريخ r/ T/11

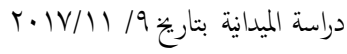

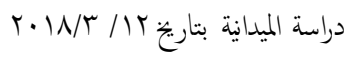

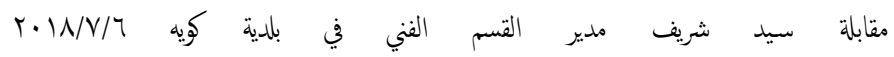

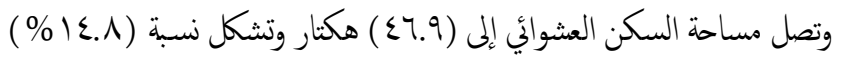
من مساحة السكن العثوائي في المدينة.

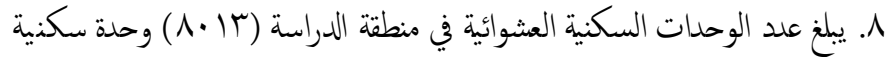

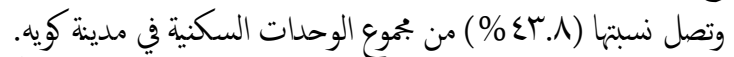

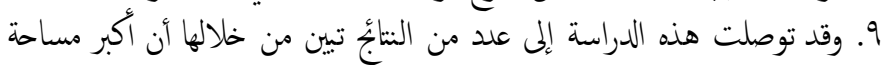

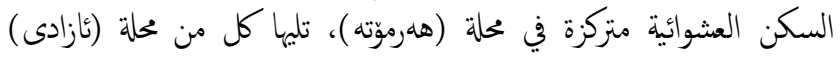

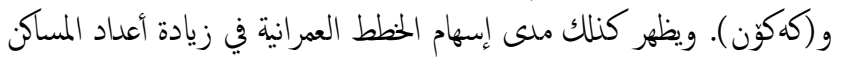

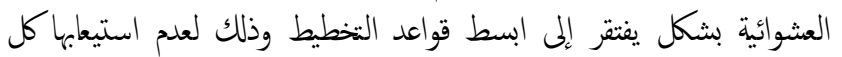

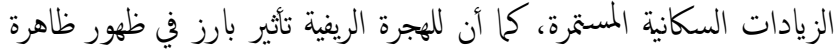

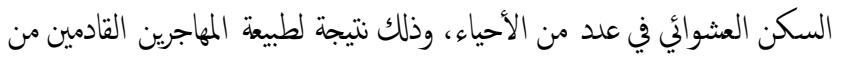

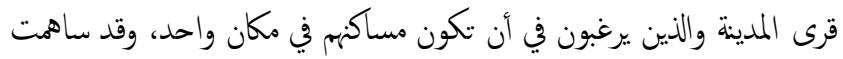

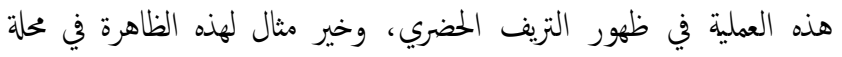

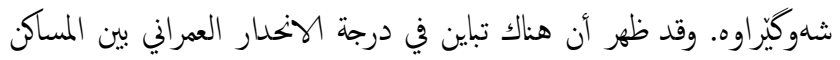

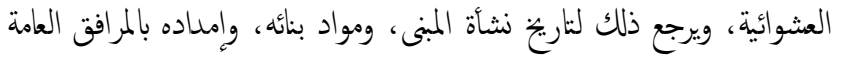
والخدمات.

•1. هناك عدة اسباب تؤدي إلى الجاه الناس إلى البناء خارج المخططات والتصميم

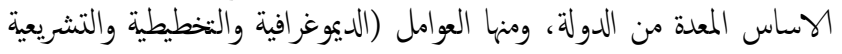

والسياسية والاقتصادية والاجتماعية).

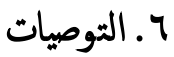

لإيجاد حلول أمثل لمشكلة السكن العشوائي بمدينة كويه توصلت الدارسة إلى ما يأتي: 1. وضع خطة استراتيجية واضحة لإعادة تخطيط المساكن العشوائية.

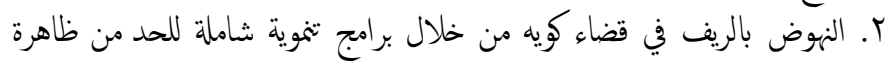
الهجرة الداخلية للمراكز الحضرية.

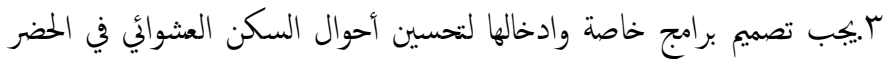
واحوال عدبي السكن. ع.توفير الخنمات والبنى النتية (الماءو والكهرباء والمجاري.... الح) في المناطق السكن العشوائي 0.ضرورة الاسراع بتنفيذ الخطط الهسكانية لوقق التعديات على الاراضي الحكومية والاراضي الزراعية. 7.التوسع في نشر ثقافة السكن العشوائي بدلاً من السكن الافتي للاستفادة من المساحات الخالية للخطط المستقبلية.

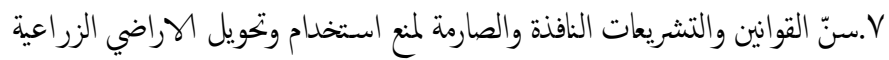
والمساحات الخالية والخدمية الى السكنية.

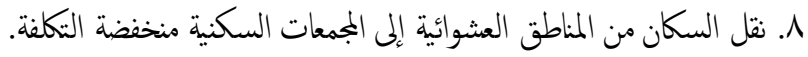

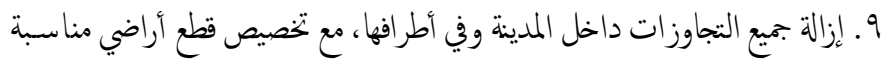

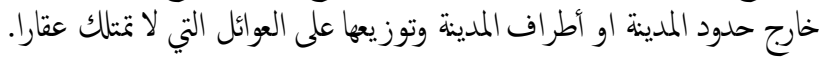

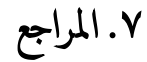

بدوي، أحمد زكي معجم المصطلحات العلوم الاجتماعية، بدون سنة الطبع، ص.7. توما جورج تومت، العوامل المؤثرة في نشأة المناطق العشوائية وسياسات الارتقاء مجلة جامعة 


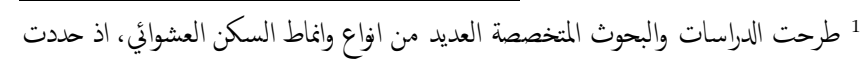

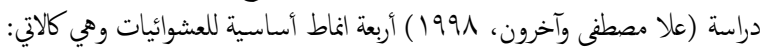

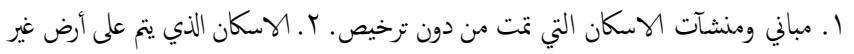
مخصصة للبناء. r. الاسكان الذي يتم على أرض مغتصبة أو غنر مملوكة لحائزها. ع. المباني الواقعة خارج تخطيط المدينة.

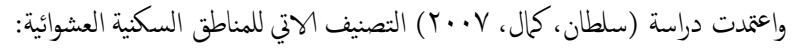

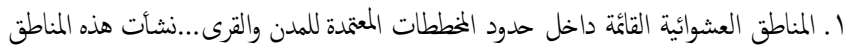

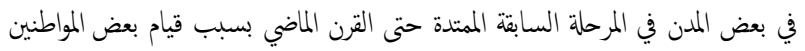

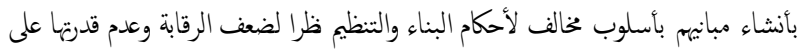
استيعاب الزيادات الهائلة والسريعة في عدد السكان.

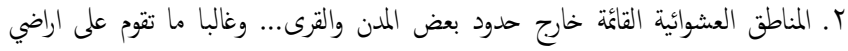
زراعية او تلك غير المخصصة للسكن.

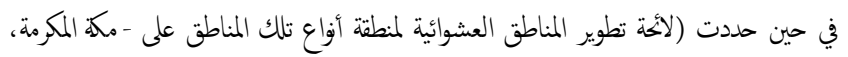

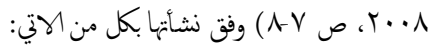

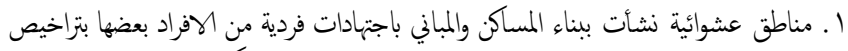

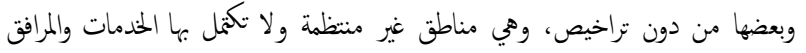

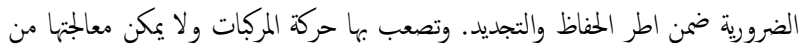
خلال برامج التنمية العمرانية الاعتيادية.

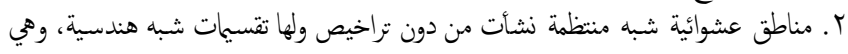

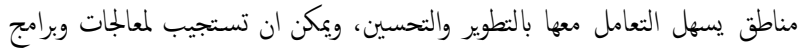
التنمية العمرانية المختلفة. r. المنطقة التاريخية او المواقع التقليدية القديمة، التي تمثل النسيج العضوي التقليدي الخططط

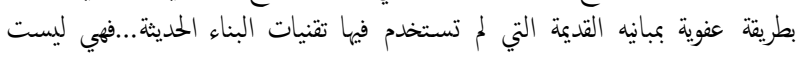

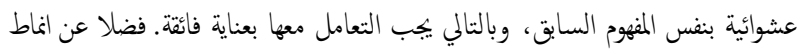
اخرى. 2 وهي المحلات (بهفر قندي، قلعة، بايز ئاغا، هواوان)

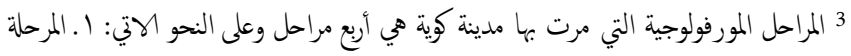

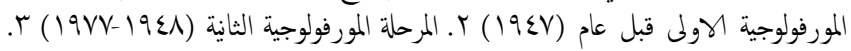

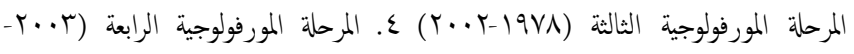

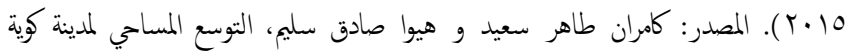

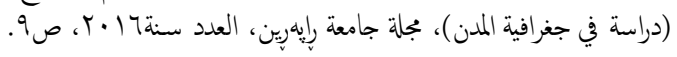

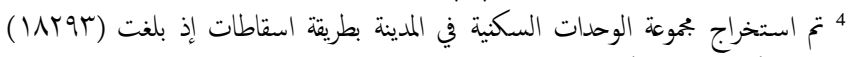
وحدة السكنية في مدينة كويه. 5 تم تصنيف المساحات السكن العشوائي داخل المدينة إلى ثلاث فئات:

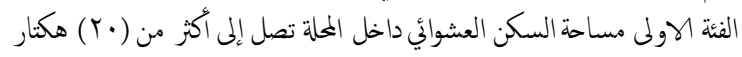

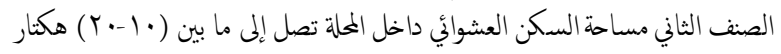

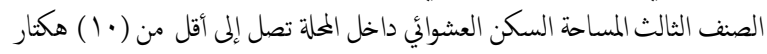
6 نسبة إلى صاحب تلك الاراضي الزراعية باسم (مام علي) التي يقع في أطراف مدينة كوية الماني آنذاك. أن التحضر المتزايد والمستمر في المدينة أدى إلى تفاقم مشكلة السكن وهي من أهم الأسباب التي

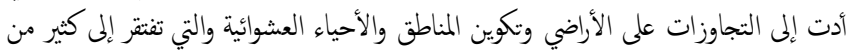

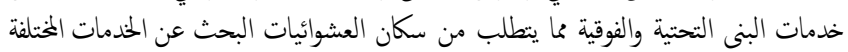

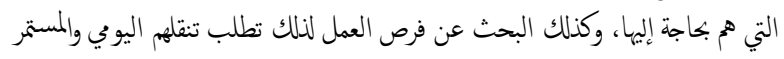

